Us. Army Const. Eng. Res, (Atr. iech. Rep. REMiz-Co

REPAIR, EVALUATION, MAINTENANCE, AND REHABILITATION RESEARCH PROGRAM

TECHNICAL REPORT REMR-CO-4

\title{
STABILITY OF DOLOS AND TRIBAR OVERLAYS FOR REHABILITATION OF STONE-ARMORED RUBBLE-MOUND BREAKWATER AND JETTY TRUNKS SUBJECTED TO BREAKING WAVES
}

\author{
by \\ Robert D. Carver, Brenda J. Wright \\ Coastal Engineering Research Center \\ DEPARTMENT OF THE ARMY \\ Waterways Experiment Station, Corps of Engineers \\ PO Box 631, Vicksburg, Mississippi 39180-0631
}

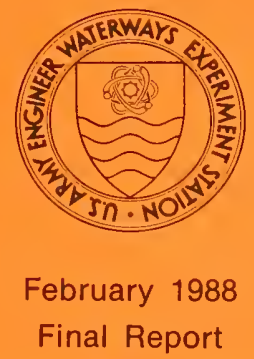

Approved For Public Release; Distribution Unlimited

Prepared for DEPARTMENT OF THE ARMY

US Army Corps of Engineers

Washington, DC 20314-1000

Under REMR Work Unit 32325 
The following two letters used as part of the number designating technical reports of research published under the Repair, Evaluation, Maintenance, and Rehabilitation (REMR) Research Program identify the problem area under which the report was prepared:

\begin{tabular}{|c|c|c|c|}
\hline & Problem Area & & Problem Area \\
\hline CS & Concrete and Steel Structures & EM & Electrical and Mechanical \\
\hline GT & Geotechnical & El & Environmental Impacts \\
\hline HY & Hydraulics & $O M$ & Operations Management \\
\hline & Coastal & & \\
\hline
\end{tabular}

Destroy this report when no longer needed. Do not return it to the originator.

The findings in this report are not to be construed as an official Department of the Army position unless so designated by other authorized documents.

The contents of this report are not to be used for advertising. publication, or promotional purposes. Citation of trade names does not constitute an official endorsement or approval of the use of such commercial products.

\section{COVER PHOTOS:}

TOP - Field Research Facility, Duck, North Carolina.

BOTTOM - Testing of a repair option for the San Pedro Breakwater. 
Unclassified

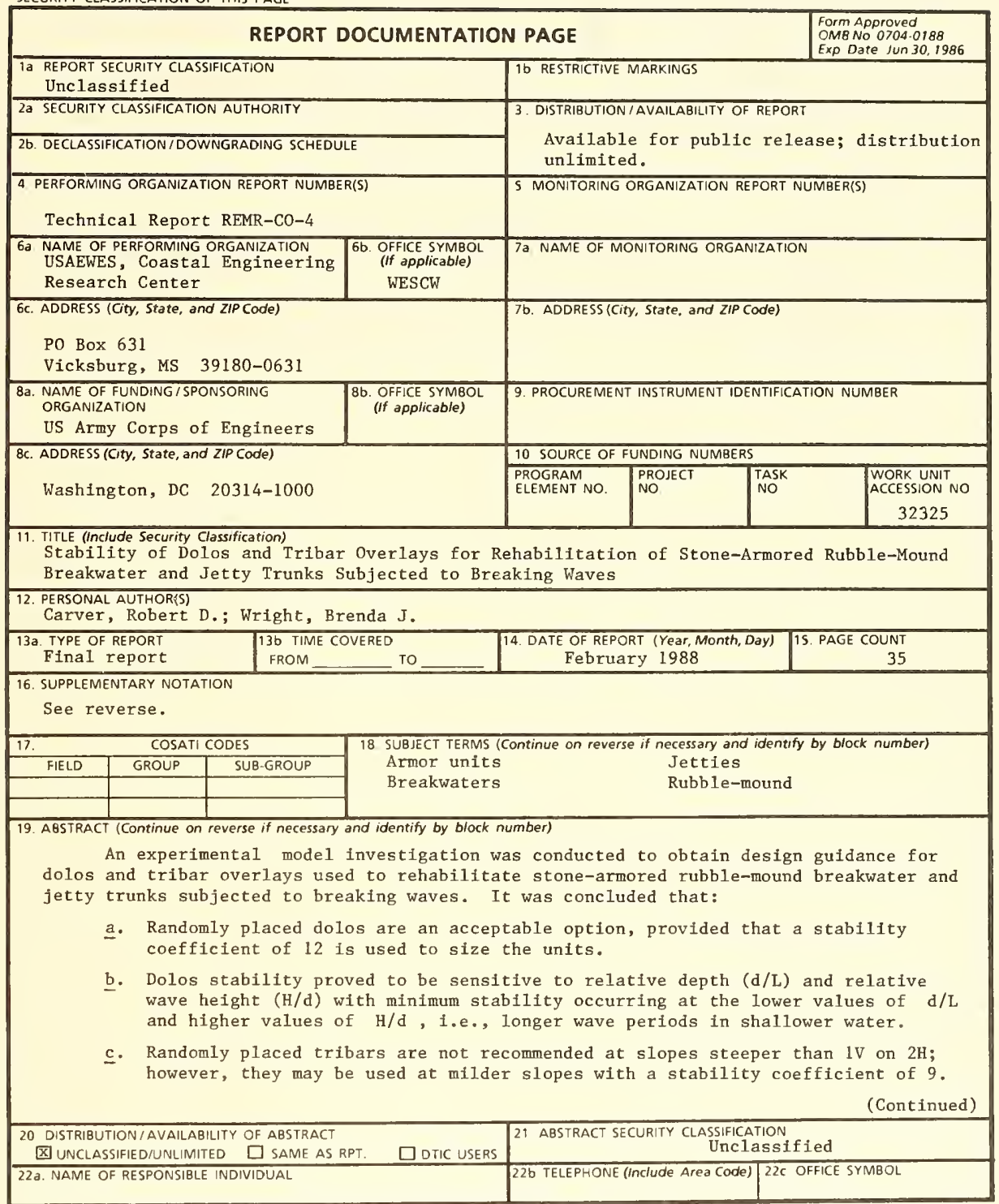


16. SUPPLEMENTARY NOTATION (Continued).

A report of the coastal problem area of the Repair, Evaluation, Maintenance, Rehabilitation (REMR) Research Program is available from National Technical Information Service, 5285 Port Royal Road, Springfield, VA 22161.

19. ABSTRACT (Continued).

d. Uniformly placed tribars are an acceptable option for a IV-on-1.5H slope, provided they are used in concert with toe buttressing stone, size selection is based on a stability coefficient of 7 , and placement of the units replicates that used in the model.

e. Tribar stability appears to be insensitive to $\mathrm{d} / \mathrm{L}$ and $\mathrm{H} / \mathrm{d}$ for both types of placement. 
Authority to carry out this investigation was granted the US Army Engineer Waterways Experiment Station's (WES) Coastal Engineering Research Center (CERC) by the Headquarters, US Army Corps of Engineers (HQUSACE), under the Repair, Evaluation, Maintenance, and Rehabilitation (REMR) Research Program Work Unit No. 32325, "Use of Dissimilar Armor for Repair and Rehabilitation of Rubble-Mound Coastal Structures."

Tests of dolos and tribar overlays for existing armor stone, which fulfill one milestone of this work unit, were conducted under the general direction of Mr. James E. Crews, and Dr. Tony C. Liu, REMR Overview Committee, HQUSACE; Messrs. Jesse A. Pfeiffer, Jr., Directorate of Research and Development, HQUSACE; John W. Lockhart, Coastal Technical Monitor, HQUSACE; and William F. McCleese, REMR Program Manager, WES, and D. D. Davidson, REMR Coastal Problem Area Leader.

The study was conducted by personnel of CERC under the general direction of Dr. James R. Houston, Chief, CERC, Mr. Charles C. Calhoun, Jr., Assistant Chief, CERC, Mr. C. E. Chatham, Chief, Wave Dynamics Division, and Mr. Davidson, former Chief, Wave Research Branch. Tests were planned by Mr. R. D. Carver, Principal Investigator, and Ms. B. J. Wright, Civil Engineering Technician, both of the Wave Research Branch, CERC. The model was operated by Ms. Wright, assisted by Mr. Frank James, Engineering Technician, and Mr. Greg Gastre11, Engineering Aid, under the supervision of Mr. Carver. This report was prepared by Mr. Carver and Ms. Wright.

Commander and Director of WES at the time of publication of this report was COL Dwayne G. Lee, CE. Technical Director was Dr. Robert W. Whalin. 
PREFACE

CONVERSION FACTORS, NON-SI TO SI (METRIC)

UNITS OF MEASUREMENT............................... 3

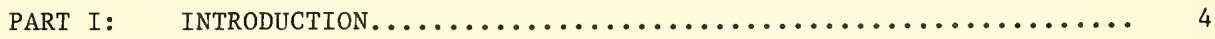

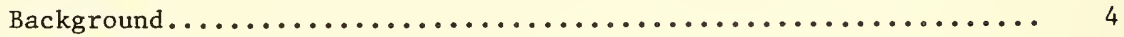

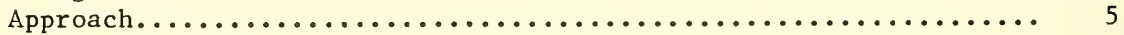

Purpose of study.................................... 5

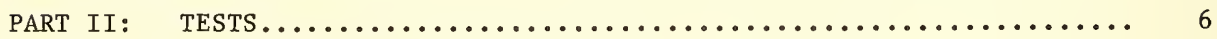

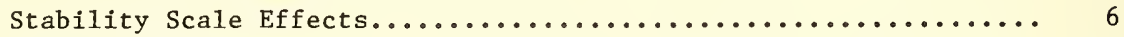

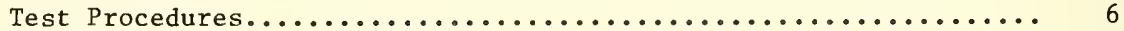

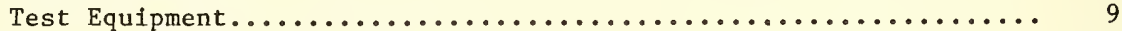

Selection of Test Conditions........................ 10

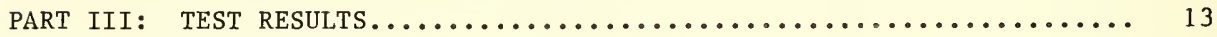

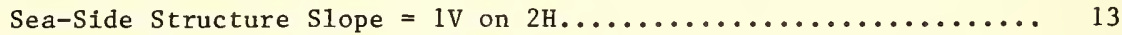

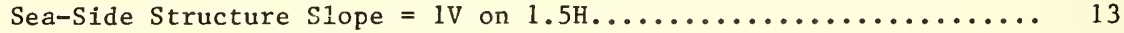

PART IV: CONCLUSIONS............................. 17

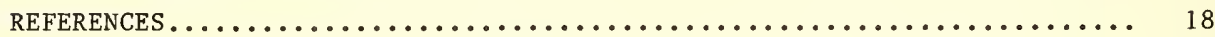

TABLES 1 and 2

PHOTOS 1-19

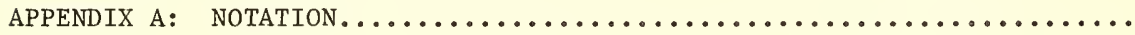




\section{CONVERSION FACTORS, NON-SI TO SI (METRIC) UNITS OF MEASUREMENT}

\begin{tabular}{|c|c|c|}
\hline Multiply & By & To Obtain \\
\hline degrees (angle) & 0.01745329 & radians \\
\hline feet & 0.3048 & metres \\
\hline inches & 25.4 & millimetres \\
\hline pounds (mass) & 0.4535924 & kilograms \\
\hline $\begin{array}{l}\text { pounds (mass) per cubic foot } \\
\text { square feet }\end{array}$ & $\begin{array}{l}16.01846 \\
0.09290304\end{array}$ & $\begin{array}{l}\text { kilograms per cubic metre } \\
\text { square metres }\end{array}$ \\
\hline tons (mass) per square foot & $9,764.856$ & kilograms per square metre \\
\hline
\end{tabular}




\section{STABILITY OF DOLOS AND TRIBAR OVERLAYS FOR REHABILITATION \\ OF STONE-ARMORED RUBBLE-MOUND BREAKWATER AND JETTY \\ TRUNKS SUBJECTED TO BREAKING WAVES}

\section{PART I: INTRODUCTION}

\section{Background}

1. The experimental investigation described herein constitutes a portion of a research effort to provide engineering data for the effective and economical rehabilitation of rubble-mound breakwaters and jetties. In this study, a rubble-mound breakwater or jetty is defined as a protective structure constructed with a core of quarry-run stone, sand, or slag and protected from wave action by one or more stone underlayers and a cover layer composed of selected quarrystone or specially shaped concrete armor units.

2. Previous investigations under Work Unit No. 31269, "Stability of Breakwaters," have yielded a significant quantity of design information for new construction using quarrystone (Hudson 1958 and Carver 1980, 1983), tetrapods, quadripods, tribars, modified cubes, hexapods, and modified tetrahedrons (Jackson 1968), dolosse (Carver and Davidson 1977 and Carver 1983), and toskane (Headquarters, US Army Corps of Engineers 1978). Rehabilitation projects on several of the Corps' rubble-mound structures have revealed a total lack of design guidance or even information concerning the interfacing and stability response of armor units that are of dissimilar type and/or size. In the past, selection of new armor type, method of interfacing, and procedures for preparation of the existing section have been based on engineering judgment or, more recently, on site-specific model studies. The engineering judgment process may be expensive since experience is limited and a solid basis seldom exists. This process can lead to recurring failures that cost millions of dollars without developing a real solution to the long-term problem. Sitespecific model studies have provided good singular solutions, but sitespecific data usually fail to meet the requirements of other projects (Carver 1988). It is anticipated that the problem will become more acute in future years as rehabilitation of major breakwaters and jetties becomes necessary to extend their project life or to meet greater design demands. 


\section{$\underline{\text { Approach }}$}

3. Model breakwaters and armor units are used to experimentally investigate the stability response of various armor combinations for selected structure geometries and wave conditions. It would be an extremely extensive task to comprehensively investigate all different types of existing armor units; therefore, this research effort will address only the three types (stone, dolos, and tribars) of armor most commonly used in the Corps. Selection of these armor types should give test results the widest range of applicability possible. Tests will be conducted with breaking wave conditions on no-damage, no-overtopping breakwater trunk and head sections by using sea-side slopes of $1 \mathrm{~V}$ on $1.5 \mathrm{H}$ and $1 \mathrm{~V}$ on $2 \mathrm{H}$.

\section{Purpose of Study}

4. The purpose of the present investigation was to obtain design guidance for dolos and tribar overlays used to rehabilitate stone-armored rubble-mound breakwater and jetty trunks subjected to breaking waves. More specifically, it was desired to determine the minimum weight of individual armor units (with given specific weights) required for stability as a function of the type of armor unit, sea-side slope of the structure, wave period, wave height, and water depth. 


\section{PART II: TESTS}

\section{Stability Scale Effects}

5. If the absolute sizes of experimental breakwater materials and wave dimensions become too small, flow around the armor units enters the laminar regime; and the induced drag forces become a direct function of the Reynolds number. Under these circumstances prototype phenomena are not properly simulated, and stability scale effects are induced. Hudson (1975) presents a detailed discussion of the design requirements necessary to ensure the preclusion of stability scale effects in small-scale breakwater tests and concludes that scale effects will be negligible if the Reynolds stability number $\left(\mathrm{R}_{\mathrm{N}}\right) *$

$$
\mathrm{R}_{\mathrm{N}}=\frac{\mathrm{g}^{1 / 2} \mathrm{H}^{1 / 2} \ell_{\mathrm{a}}}{v}
$$

where

$$
\begin{aligned}
g & =\text { acceleration due to gravity, } \mathrm{ft} / \mathrm{sec}^{2} \\
\mathrm{H} & =\text { wave height, } \mathrm{ft} \\
\ell_{\mathrm{a}} & =\text { characteristic length of armor unit, ft } \\
\nu & =\text { kinematic viscosity }
\end{aligned}
$$

is equal to or greater than $3 \times 10^{4}$. For all tests reported herein, the sizes of experimental armor and wave dimensions were selected such that scale effects were insignificant (i.e., $\mathrm{R}_{\mathrm{N}}$ was greater than $3 \times 10^{4}$ ).

\section{Test Procedures}

\section{Method of constructing test sections}

6. All experimental breakwater sections were constructed to reproduce as closely as possible results of the usual methods of constructing full-scale breakwaters. The core material was dampened as it was dumped by bucket or shovel into the flume and was compacted with hand trowels to simulate natural consolidation resulting from wave action during construction of the prototype

* Symbols are identified in Appendix A. 
structure. Once the core material was in place, it was sprayed with a low-velocity water hose to ensure adequate compaction of the material. The underlayer stone was then added by shovel and smoothed to grade by hand or with trowels. No excessive pressure or compaction was applied during placement of the underlayer stone. Armor units used in the cover layers were placed in a random manner corresponding to work performed by a general coastal contractor; i.e., they were individually placed but were laid down without special orientation or fitting. After each test series the armor units were removed from the breakwater, all of the underlayer stones were replaced to the grade of the original test section, and the armor was replaced. Selection of critically breaking waves

7. For the given wave period and water depth, the most detrimental breaking wave (i.e., the most damaging wave) was determined by increasing the stroke adjustment on the wave generator in small increments and observing which wave produced the most severe breaking wave condition on the experimental structures. Wave heights of lower amplitude did not form the critical breaking wave and wave heights of larger amplitude would break seaward of the test structures and dissipate their energy so that they were less damaging than the critically tuned wave.

8. A typical stability test series consisted of subjecting the test sections to attack by waves of given heights and periods until all damage had abated or the structures failed. Test sections were subjected to wave attack in approximately $30-\mathrm{sec}$ intervals between which the wave generator was stopped and the waves were allowed to decay to zero height. This procedure was necessary to prevent the structures from being subjected to an undefined wave system created by reflections from the experimental breakwater and wave generator. Newly built test sections were subjected to a short duration (five or six 30-sec intervals) of shakedown by using a wave equal in height to about one-half of the design wave. This procedure provided a means of allowing consolidation and armor unit seating that would normally occur during prototype construction.

Method of determining damage

9. In order to evaluate and compare breakwater stability test results, it is necessary to quantify the changes that have taken place in a given structure during attack by waves of specified characteristics. The US Army Engineer Waterways Experiment Station (WES) developed a method of measuring 
the percent damage incurred by a test section during the early 1950's. This method has proven satisfactory and was used as a means for analyzing and comparing the stability tests delineated within this report.

10. The WES damage-measurement technique requires that the crosssectional area occupied by armor units be determined for each stability test section. Armor unit area is computed from elevations (soundings) taken at closely spaced grid-point locations before the armor is placed on the underlayer, after the armor has been placed but before the section has been subjected to wave attack, and finally after wave attack. Elevations are obtained with a sounding rod equipped with a circular spirit level for plumbing, a scale graduated in thousandths of a foot, and a ball-and-socket foot for adjustment to the irregular surface of the breakwater slope. The diameter (Diam) in inches of the circular foot of the sounding rod was related to the size of the material being sounded by the following equation:

where

$$
\text { Diam }=C\left(\frac{w_{a}}{\gamma_{a}}\right)^{1 / 3}
$$

$$
\begin{aligned}
C & =\text { coefficient } \\
W_{a} & =\text { weight of an armor unit, } 1 b \\
\gamma_{a} & =\text { specific weight of armor unit, pcf }
\end{aligned}
$$

$\mathrm{C}=6.8$ for tribars and stone and 13.7 for dolosse. A series of sounding tests in which both the weight of the armor and the diameter of the sounding foot were varied indicated that the above relation would give a. measured thickness which visually appeared to represent an acceptable two-layer thickness.

11. Sounding data for each test section were obtained as follows: after the underlayer was in place, soundings were taken on the slopes of the structure along rows beginning at and parallel to the longitudinal center line of the structure and extending in $0.25-\mathrm{ft}$ horizontal increments until the edge of the armor was reached. On each parallel row, sounding points, spaced at 0.25-ft increments, were measured. The $0.5 \mathrm{ft}$ of structure next to each wal1 was not considered because of the possibility of discontinuity effects between armor units and the flume walls. Soundings were taken at the same points once

* A table of factors for converting non-SI units of measurement to SI (metric) units is presented on page 3 . 
the armor was in place and again after the structure had been subjected to wave attack.

12. Sounding data from each stability test were reduced in the following manner. The individual sounding points obtained on each parallel row were averaged to yield an average elevation at the bottom of the armor layer before the armor was placed and then at the top of the armor layer before and after testing. From these values, the cross-sectional armor area before testing and the area from which armor units were displaced (either downslope or off the section) were calculated. Damage was then determined from the following relation:

$$
\text { Percent damage }=\frac{A_{2}}{A_{1}}(100)
$$

where

$A_{2}=$ area from which armor units have been displaced, $f t^{2}$

$\mathrm{A}_{1}=$ area before testing, $\mathrm{ft}^{2}$

The percentage given by the WES sounding technique is, therefore, a measurement of an end area which converts to an average volume of armor material that has been moved from its original location (either downslope or off-structure).

\section{Test Equipment}

13. Al1 tests were conducted in a 5-ft-wide, 4-ft-deep, 119-ft-long concrete wave flume with test sections installed about $90 \mathrm{ft}$ from a vertical displacement wave generator. A thin divider was installed in the center of the test section area, thus yielding two 2.5-ft-wide sections. The first 10-ft length of flume bottom, immediately seaward of the test sections, was molded on a $1 \mathrm{~V}-\mathrm{on}-10 \mathrm{H}$ slope while the remaining $80-\mathrm{ft}$ length was flat. The generator is capable of producing sinusoidal waves of various periods and heights. For all tests, waves of the required characteristics were generated by varying the frequency and amplitude of the plunger motion. Changes in water-surface elevation as a function of time (wave heights) were measured by electrica1 wave-height gages in the vicinity of where the toe of the test sections was to be placed (without the structure in place) and recorded on 
chart paper by an electrically operated oscillograph. The electrical output of the wave gages was directly proportional to their submergence depth.

\section{Selection of Test Conditions}

14. Breaking wave tests were conducted using both tribar and dolos armor overlays. A review of past site-specific stability projects and hydrographic data showed that typical prototype sea-bottom slopes could range from almost flat to as steep as $1 \mathrm{~V}$ on $10 \mathrm{H}$. Severity of breaking action increases as bottom slope increases and since time restraints would allow testing of only one foreslope, it was decided to use a $1 \mathrm{~V}$-on-10H slope, thus ensuring severe depth-limited breaking wave action (plunging breakers). When breaking directly on the structure, this type of wave normally causes the most damage to rubble-mound structures.

15. By nondimensionalizing design conditions from site-specific projects, it was found that a relative depth $(\mathrm{d} / \mathrm{L})$ range of 0.04 to 0.14 should include most prototype conditions encountered in breaking-wave stability designs. A review of capabilities of the available flume and wave generator showed that this range of $d / L$ values could be achieved for a reasonable range of testing depths.

16. The wave flume was calibrated for depths from 0.40 to $0.95 \mathrm{ft}$ in $0.05-\mathrm{ft}$ increments at $\mathrm{d} / \mathrm{L}$ values of $0.04,0.06,0.08,0.10,0.12$, and 0.14 . This range of depths, and consequently breaking wave heights, proved to be compatible with the selected armor weights and sea-side breakwater slopes.

17. All stability tests were conducted on sections of the type shown in Figure 1 and Photos 1-3. Sea-side slopes of $1 \mathrm{~V}$ on $1.5 \mathrm{H}$ and $1 \mathrm{~V}$ on $2 \mathrm{H}$ were investigated while the beach-side slope was held constant at $1 \mathrm{~V}$ on $1.5 \mathrm{H}$. Heights of the simulated existing structures (prior to placement of the dolos or tribar overlays) varied from 1.0 to $1.4 \mathrm{ft}$. The height necessary to prevent wave overtopping of the existing structure was determined from slopes and estimated water depths and wave heights to be investigated in determining stability coefficients ( $\mathrm{K}_{\mathrm{D}}^{\prime} \mathrm{s}$ ) for the dissimilar armor overlays.

18. It was assumed that the existing armor stone was only marginally stable and the dolos and tribar overlays would have $\mathrm{K}_{\mathrm{o}}$ equal to those obtained in new construction. Based on these assumptions, the stable tribar weights would be approximately equal to the weight of the existing armor stone 


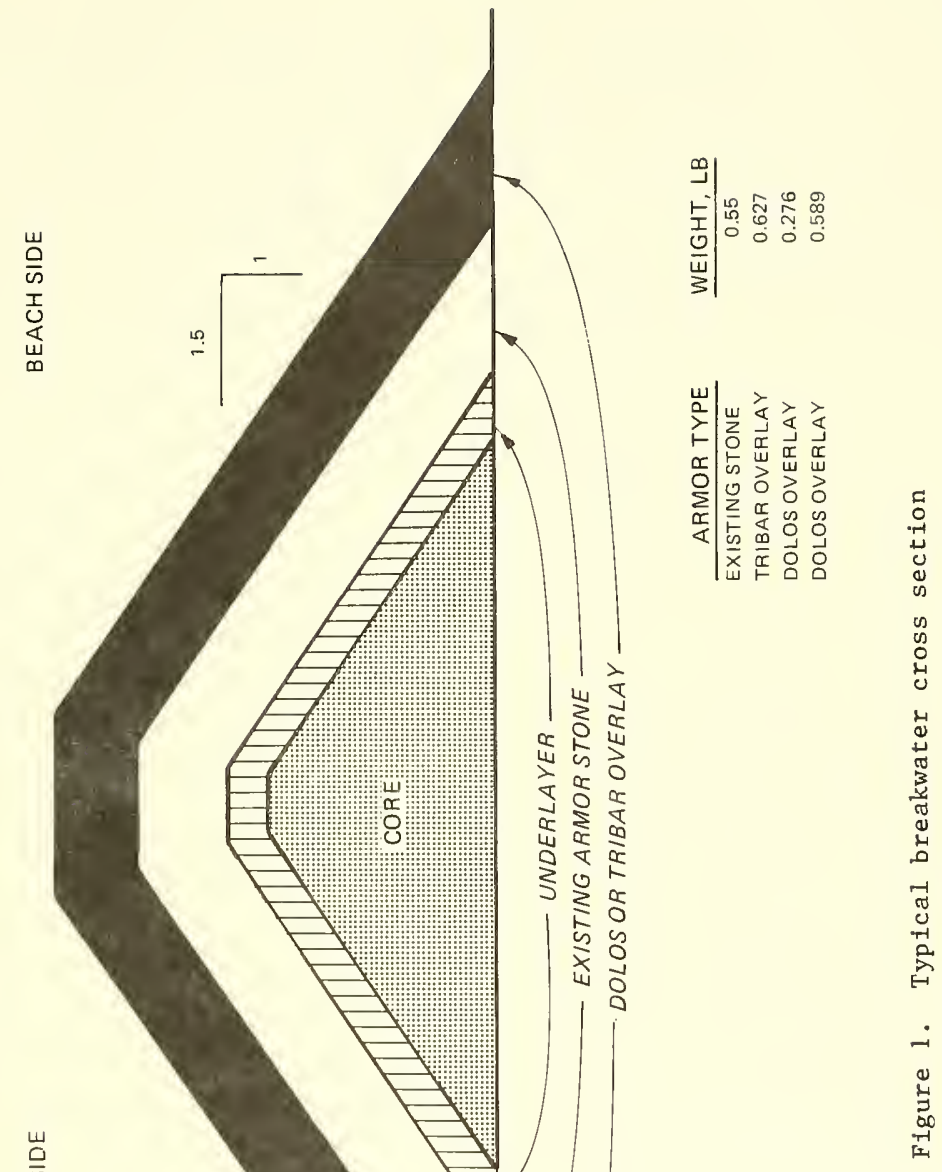


and the dolos weights would vary from one-half up to the armor stone weight, depending on the degree of conservatism used in their selection. A review of existing model materials was made in concert with these assumptions and a 0.55-1b stone was selected to simulate existing conditions. Tests were conducted using $0.627-1 \mathrm{~b}$ tribar overlays and $0.276-$ and $0.589-1 \mathrm{~b}$ dolos overlays. 


\section{$\underline{\text { Sea-Side Structure Slope }=\text { IV on } 2 \mathrm{H}}$}

19. Stability test results for dolos and tribar overlays constructed on a $1 \mathrm{~V}-\mathrm{on}-2 \mathrm{H}$ slope are summarized in Table 1. Presented herein are experimentally determined $K_{D}^{\prime} s$ as functions of $d / L$ and relative wave height (H/d). The stability coefficient, $K_{D}$, is determined from the Hudson formula, i.e.,

$$
W_{a}=\frac{\gamma_{a} H^{3}}{K_{D}\left(S_{a}-1\right)^{3} \cot \alpha}
$$

where

$$
\begin{aligned}
& \mathrm{K}_{\mathrm{D}}=\text { stability coefficient } \\
& \mathrm{S}_{\mathrm{a}}=\text { specific gravity of armor unit } \\
& \alpha=\text { reciprocal of breakwater slope }
\end{aligned}
$$

Armor units were placed randomly in two layers and the number of armor units per given surface area was equal to that presently recommended for new construction in EM 1110-2-2904, "Design of Breakwaters and Jetties" (Headquarters, Department of the Army 1986). Photos 4-10 show typical after-testing conditions of structures.

20. Figures 2 and 3 present $\mathrm{K}_{\mathrm{D}}$ as a function of $\mathrm{d} / \mathrm{L}$ and $\mathrm{H} / \mathrm{d}$, respectively. These data show dolos stability to be sensitive to both $\mathrm{d} / \mathrm{L}$ and $\mathrm{H} / \mathrm{d}$ with minimum stability occurring at the lower values of $\mathrm{d} / \mathrm{L}$ and higher values of $\mathrm{H} / \mathrm{d}$, i.e., longer wave periods in shallower water. These trends are consistent with those observed by Carver (1983) for dolos used in new construction. Influences of $\mathrm{H} / \mathrm{d}$ and $\mathrm{d} / \mathrm{L}$ on tribar stability do not appear to be significant in the present data. The minimum $\mathrm{K}_{\mathrm{D}}$ observed for tribars is equal to that obtained for new construction and to that observed for dolos is about 15 percent less (12.8 versus 15).

\section{Sea-Side Structure Slope $=1 \mathrm{~V}$ on $1.5 \mathrm{H}$}

21. Stability tests were initiated at the $1 \mathrm{~V}$-on-1.5H slope using dolos armor units randomly placed in two layers. Results of these tests, summarized 


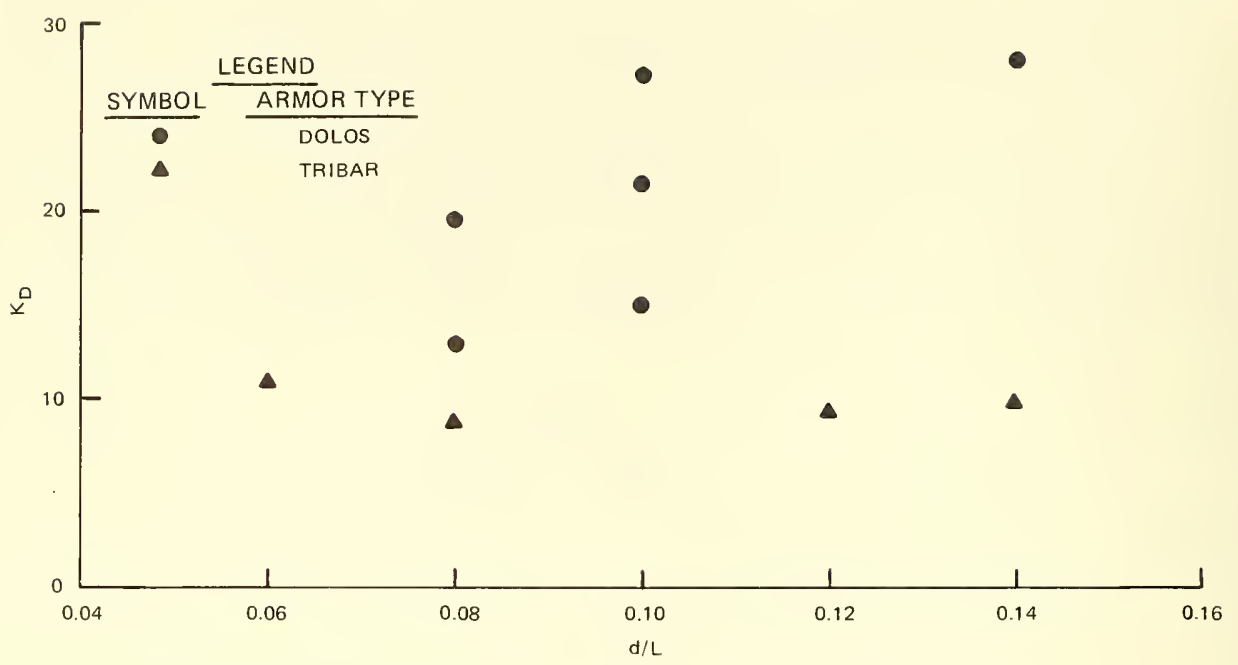

Figure 2. Stability coefficient $K_{D}$ versus relative depth $d / L$ $\cot \alpha=2.0$

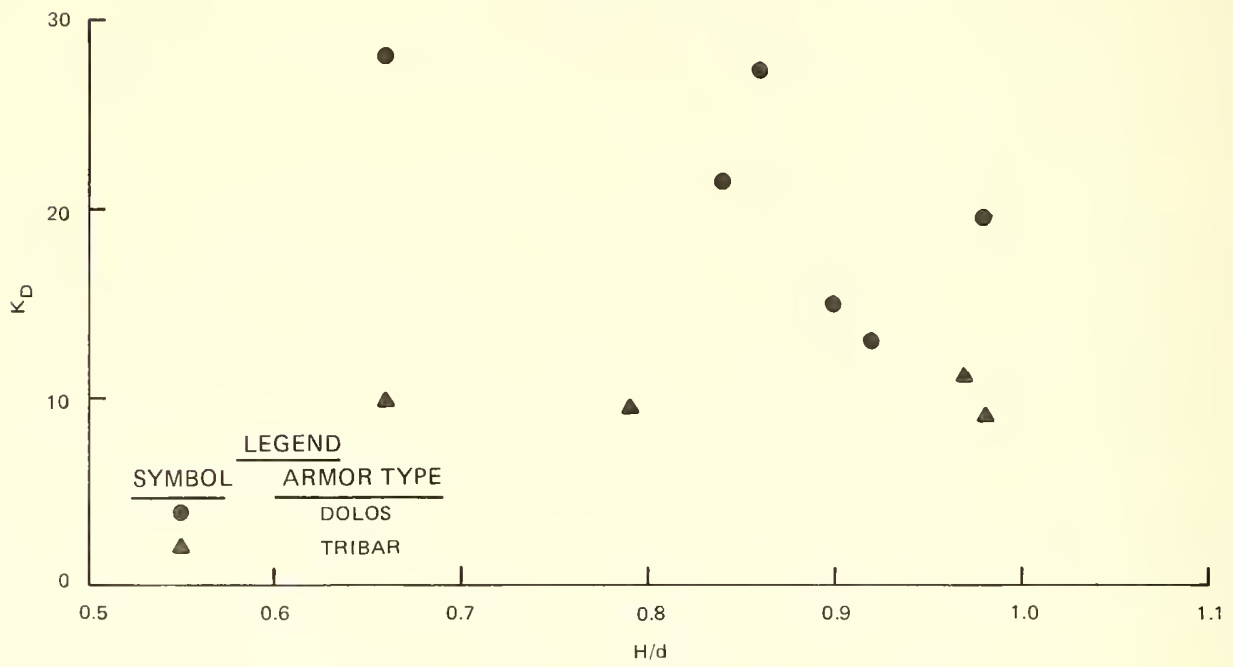

Figure 3. Stability coefficient $\mathrm{K}_{\mathrm{D}}$ versus relative wave height $\mathrm{H} / \mathrm{d}$ $\cot \alpha=2.0$ 
in Table 2 and depicted in Photos 11-14, were similar to those obtained at the $1 \mathrm{~V}$-on-2H slope. However, a slight decrease in stability was observed.

22. Tribar tests were initiated with two layers of randomly placed units and an assumed $\mathrm{K}_{\mathrm{D}}$ of 9 . This structure proved to be unstable. Wave heights were progressively reduced to $0.33 \mathrm{ft}$ without achieving stability. Generally, the tribars did not interface well with the larger armor stone at this steeper slope and were prone to downslope shifting. Photos 15 and 16 show the structure after attack of 0.38 - and $0.33-f t$ waves, respectively. If stability had been achieved, the corresponding $K_{D}^{\prime}$ s would be 4.2 and 2.7. Based on these test results, randomly placed tribars are not recommended for overlaying existing armor stone at slopes steeper than $1 \mathrm{~V}$ on $2 \mathrm{H}$.

23. Random tribar placement was tested initially because this type is generally the most economical and reliable to construct in the field. However, one layer of uniform tribar placement in concert with large toe buttressing stone has been used by Pacific Ocean Division (POD). Therefore, it was decided to investigate the stability of this configuration. Based on POD's experience, a buttressing stone weight about 1.3 times greater than the tribar weight was selected. Photo 17 shows the structure before wave attack and Photos 18 and 19 show typical after-testing views.

24. Results of stability tests for the uniformly placed tribars are summarized in Table 2 along with the previously discussed dolos test results. These data indicate a minimum stability coefficient of 7.0 for the uniformly placed tribars. Figures 4 and 5 present $K_{D}$ as a function of $d / L$ and $\mathrm{H} / \mathrm{d}$, respectively. Similar to results for the $1 \mathrm{~V}$-on-2H slope, dolos stability proved to be sensitive to $\mathrm{d} / \mathrm{L}$ and $\mathrm{H} / \mathrm{d}$ with minimum stability occurring at the lower values of $\mathrm{d} / \mathrm{L}$ and higher values of $\mathrm{H} / \mathrm{d}$ and tribar stability was not significantly influenced by either $d / L$ or $H / d$.

25. Minor rocking and shifting of the buttressing stone was observed during some of the tests; therefore, the selected weight ( 1.3 tribar weights) is recommended as a true minimum. Also, stability results achieved for the uniformly placed tribars are highly dependent on the careful placement of the tribars in concert with the buttressing stone. Specifications should clearly state that gaps between the units are not acceptable as voids invite downslope slippage and may lead to failure of the overlay. 


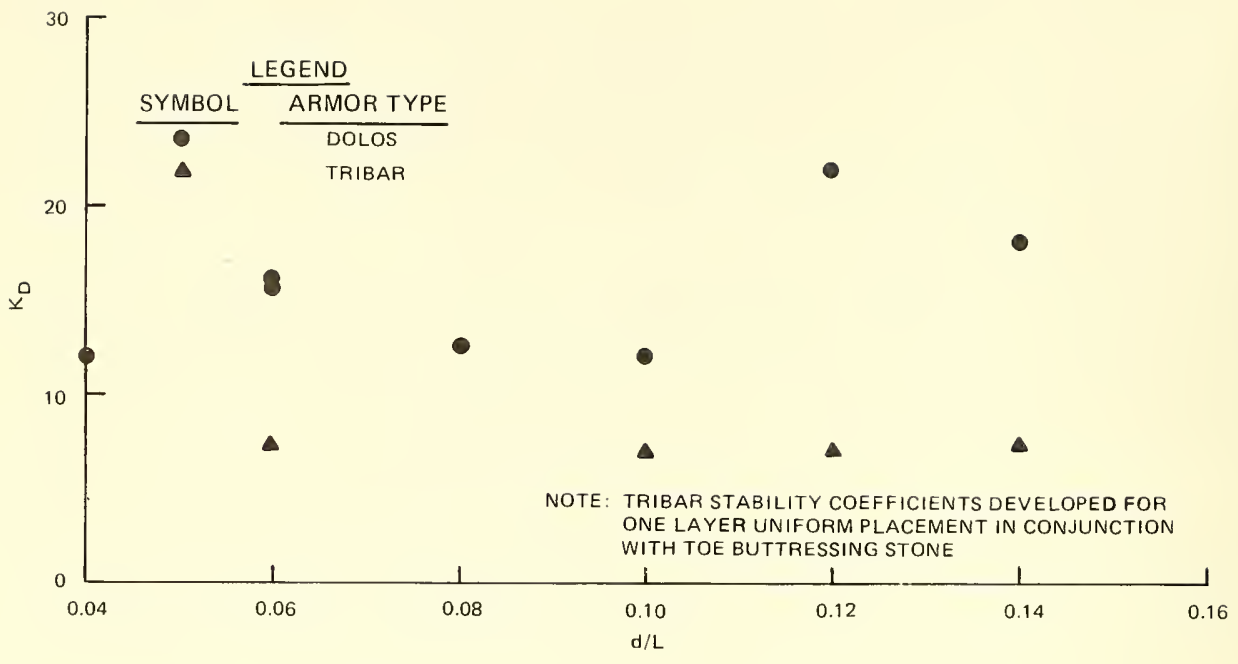

Figure 4. Stability coefficient $K_{D}$ versus relative depth $d / L$ $\cot \alpha=1.5$

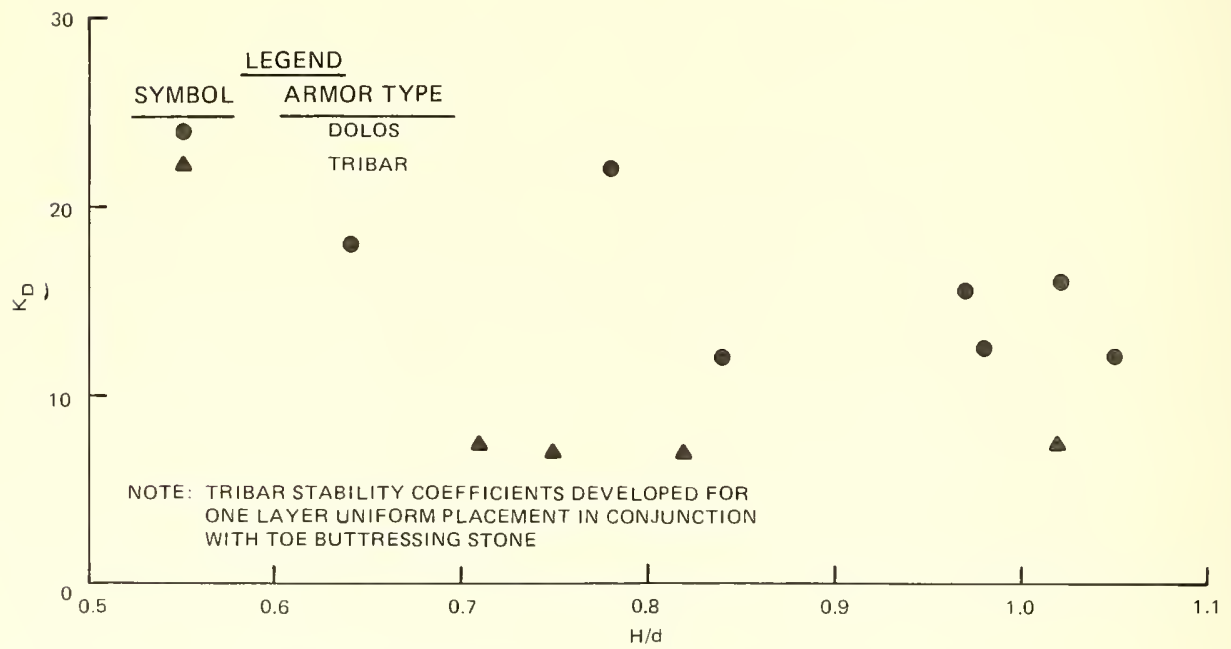

Figure 5. Stability coefficient $\mathrm{K}_{\mathrm{D}}$ versus relative wave height $\mathrm{H} / \mathrm{d}$ $\cot \alpha=1.5$ 
26. Based on tests and results described herein in which dolos and tribar armor are used to overlay existing armor stone on breakwater trunks and subjected to breaking waves with a direction of approach of $90 \mathrm{deg}$, it is concluded that:

a. Randomly placed dolos are an acceptable option, provided that a stability coefficient of 12 is used to size the units.

b. Dolos stability proved to be sensitive to $\mathrm{d} / \mathrm{L}$ and $\mathrm{H} / \mathrm{d}$ with minimum stability occurring at the lower values of $d / L$ and higher values of $\mathrm{H} / \mathrm{d}$, i.e., longer wave periods in shallower water.

c. Randomly placed tribars are not recommended at slopes steeper than $1 \mathrm{~V}$ on $2 \mathrm{H}$; however, they may be used at milder slopes with a stability coefficient of 9 .

d. Uniformly placed tribars are an acceptable option for a 1V-on$1.5 \mathrm{H}$ slope provided that they are used in concert with the buttressing stone, size selection is based on a stability coefficient of 7 , and placement of the units replicates that used in the model.

e. Tribar stability appears to be insensitive to $\mathrm{d} / \mathrm{L}$ and $\mathrm{H} / \mathrm{d}$ for both types of placement. 
Carver, R. D. 1980 (Jan). "Effects of First Underlayer Weight on the Stability of Stone-Armored Rubble-Mound Breakwater Trunks Subjected to Nonbreaking Waves with No Overtopping; Hydraulic Model Investigation," Technical Report HL-80-1, US Army Engineer Waterways Experiment Station, Vicksburg, Miss.

- 1983 (Dec). "Stability of Stone- and Dolos-Armored, Rubble-Mound Breakwater Trunks Subjected to Breaking Waves With No Overtopping," Technical Report CERC-83-5, US Army Engineer Waterways Experiment Station, Vicksburg, Miss.

- 1988. "Prototype Experience with the Use of Dissimilar Armor for

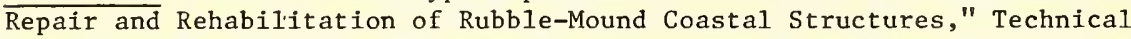
Report REMR-CO-2, US Army Engineer Waterways Experiment Station, Vicksburg, Miss.

Carver, R. D., and Davidson, D. D. 1977 (Nov). "Dolos Armor Units Used on Rubble-Mound Breakwater Trunks Subjected to Nonbreaking Waves with No Overtopping," Technical Report H-77-19, US Army Engineer Waterways Experiment Station, Vicksburg, Miss.

Headquarters, Department of the Army. 1986 (Aug). "Engineering and Design; Design of Breakwaters and Jetties," EM 1110-2-2904, Washington, DC

Headquarters, US Army Corps of Engineers. 1978. "Hydraulic Model Tests of Toskane Armor Units," Engineer Technical Letter ETL 1110-2-233, Washington, DC.

Hudson, R. Y. 1958 (JuI). "Design of Quarry-Stone Cover Layers for RubbleMound Breakwaters; Hydraulic Laboratory Investigation," Research Report No. 2-2, US Army Engineer Waterways Experiment Station, Vicksburg, Miss.

- 1975 (Jun). "Reliability of Rubble-Mound Breakwater Stability Models; Hydraulic Model Investigation," Miscellaneous Paper H-75-5, US Army Engineer Waterways Experiment Station, Vicksburg, Miss.

Jackson, R. A. 1968 (Jun). "Design of Cover Layers for Rubble-Mound Breakwaters Subjected to Nonbreaking Waves; Hydraulic Laboratory Investigation," Research Report No. 2-11, US Army Engineer Waterways Experiment Station, Vicksburg, Miss. 
Table 1

Values of $\mathrm{H}, \mathrm{d} / \mathrm{L}, \mathrm{H} / \mathrm{d}$, and $\mathrm{K}_{\mathrm{D}}$ for Dolos and Tribar Armor

Overlays of Existing Stone Armor When Subjected to Breaking

Waves; $1 \mathrm{~V}$-on-2H Structure Slope

$\underline{\mathrm{W}_{\mathrm{a}}, \mathrm{lb}} \quad \underline{\mathrm{d}, \mathrm{ft}} \quad \underline{\mathrm{T}, \mathrm{sec}} \quad \underline{\mathrm{H}, \mathrm{ft}} \quad \underline{\mathrm{d} / \mathrm{L}} \quad \underline{\mathrm{H} / \mathrm{d}} \quad \underline{K_{\mathrm{D}}}$

Dolos Armor

$\begin{array}{lllllll}0.276 & 0.55 & 1.70 & 0.54 & 0.08 & 0.98 & 19.5 \\ 0.276 & 0.95 & 1.37 & 0.61 & 0.14 & 0.66 & 27.9 \\ 0.589 & 0.65 & 1.85 & 0.60 & 0.08 & 0.92 & 12.8 \\ 0.589 & 0.70 & 1.57 & 0.63 & 0.10 & 0.90 & 14.9 \\ 0.589 & 0.85 & 1.73 & 0.71 & 0.10 & 0.84 & 21.4 \\ 0.589 & 0.90 & 1.78 & 0.77 & 0.10 & 0.86 & 27.2\end{array}$

Tribar Armor

$\begin{array}{rrrrrrr}0.627 & 0.55 & 1.70 & 0.54 & 0.08 & 0.98 & 9.0 \\ 0.627 & 0.60 & 2.32 & 0.58 & 0.06 & 0.97 & 11.2 \\ 0.627 & 0.70 & 1.34 & 0.55 & 0.12 & 0.79 & 9.5 \\ 0.627 & 0.85 & 1.30 & 0.56 & 0.14 & 0.66 & 10.1\end{array}$


Table 2

Values of $\mathrm{H}, \mathrm{d} / \mathrm{L}, \mathrm{H} / \mathrm{d}$, and $\mathrm{K}_{\mathrm{D}}$ for Dolos and Tribar Armor

Overlays of Existing Stone Armor When Subjected to Breaking Waves; $1 \mathrm{~V}$-on-1.5H Structure Slope

$\underline{W_{a}, I b} \quad \underline{d, f t} \quad \underline{T, \sec } \quad \underline{H, f t} \quad \underline{d / L} \quad \underline{H / d} \quad \underline{K_{D}}$

\section{Dolos Armor}

$\begin{array}{lllllll}0.276 & 0.40 & 2.82 & 0.42 & 0.04 & 1.05 & 12.1 \\ 0.276 & 0.45 & 2.02 & 0.46 & 0.06 & 1.02 & 15.9 \\ 0.276 & 0.50 & 1.32 & 0.42 & 0.10 & 0.84 & 12.1 \\ 0.276 & 0.65 & 1.29 & 0.51 & 0.12 & 0.78 & 21.8 \\ 0.589 & 0.55 & 1.70 & 0.54 & 0.08 & 0.98 & 12.5 \\ 0.589 & 0.60 & 2.32 & 0.58 & 0.06 & 0.97 & 15.6 \\ 0.589 & 0.95 & 1.37 & 0.61 & 0.14 & 0.64 & 18.0\end{array}$

Tribar Armor

$\begin{array}{lllllll}0.627 & 0.45 & 2.02 & 0.46 & 0.06 & 1.02 & 7.4 \\ 0.627 & 0.55 & 1.39 & 0.45 & 0.10 & 0.82 & 7.0 \\ 0.627 & 0.60 & 1.24 & 0.45 & 0.12 & 0.75 & 7.0 \\ 0.627 & 0.65 & 1.13 & 0.46 & 0.14 & 0.71 & 7.4\end{array}$




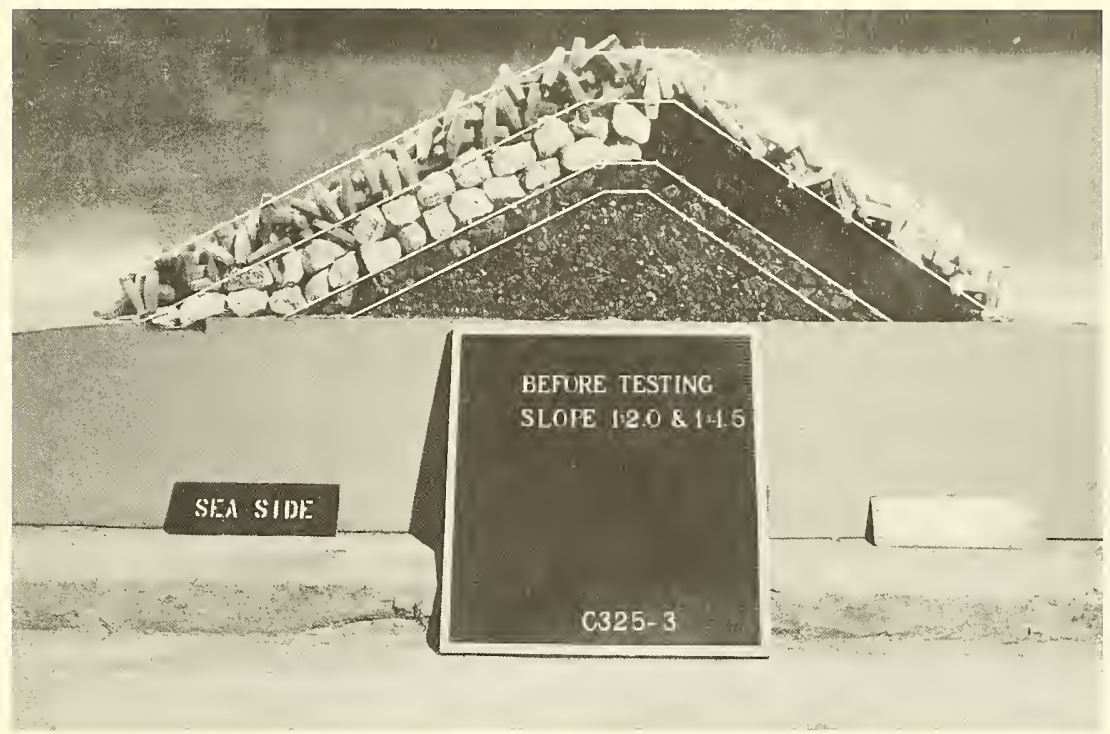

Photo 1. End view of a typical dolos section before wave attack at a $1 \mathrm{~V}$-on-2H sea-side structure slope; $\mathrm{W}_{\mathrm{a}}=0.276 \mathrm{lb}$

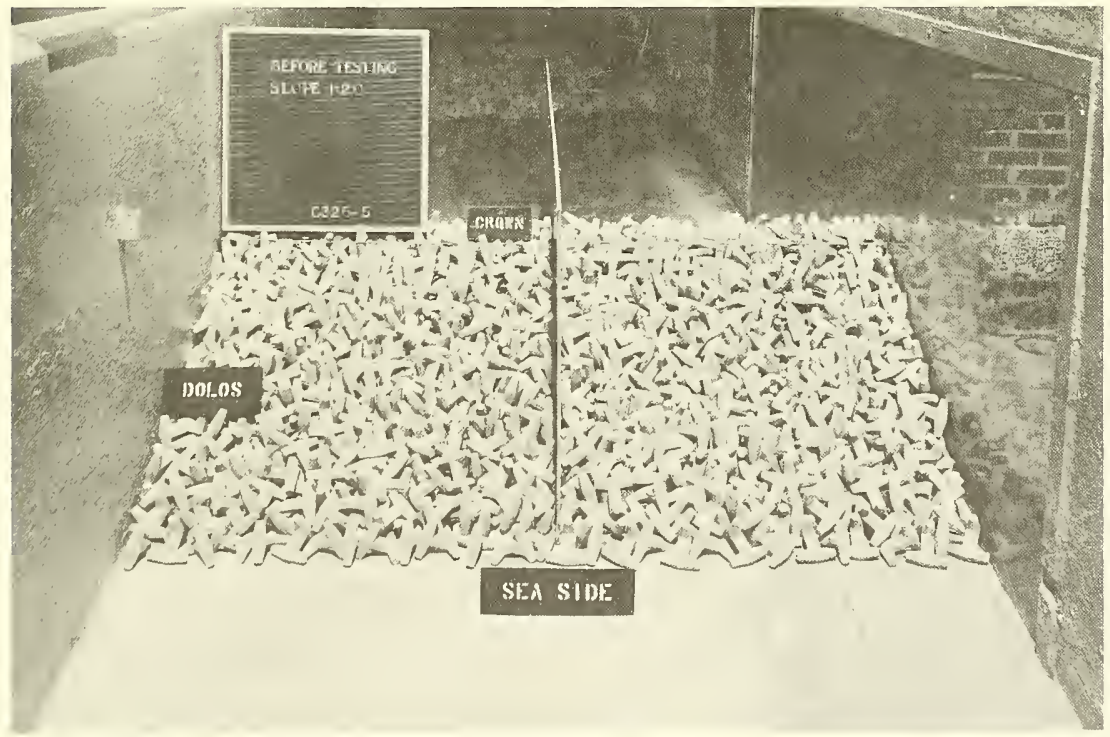

Photo 2. Sea-side view of a typical dolos section before wave attack at a $1 \mathrm{~V}-\mathrm{on}-2 \mathrm{H}$ sea-side structure slope; $\mathrm{W}_{\mathrm{a}}=0.276 \mathrm{Ib}$ 


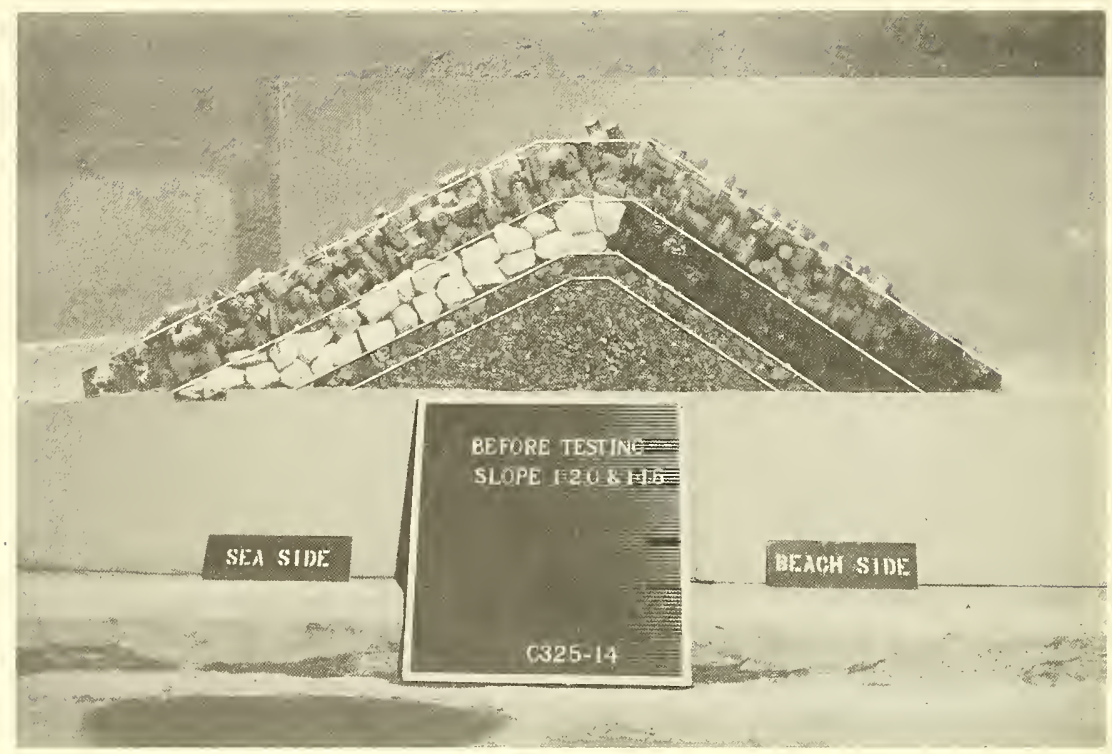

Photo 3. End view of a typical tribar section before wave attack at a $1 \mathrm{~V}$-on-2H sea-side structure slope; $\mathrm{W}_{\mathrm{a}}=0.627 \mathrm{lb}$

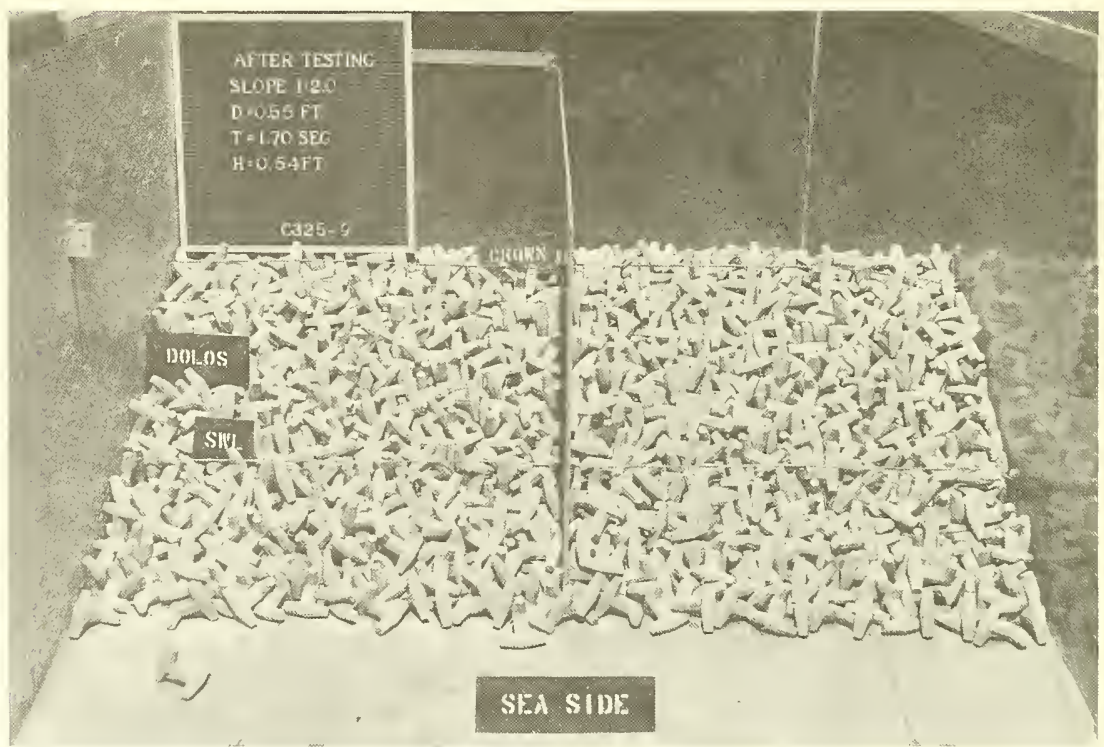

Photo 4. Sea-side view after attack of 1.70-sec, 0.54-ft waves; $\mathrm{d}=0.55 \mathrm{ft} ; \mathrm{W}_{\mathrm{a}}=0.276 \mathrm{lb} ; 1 \mathrm{~V}$-on-2H structure slope; dolos armor 


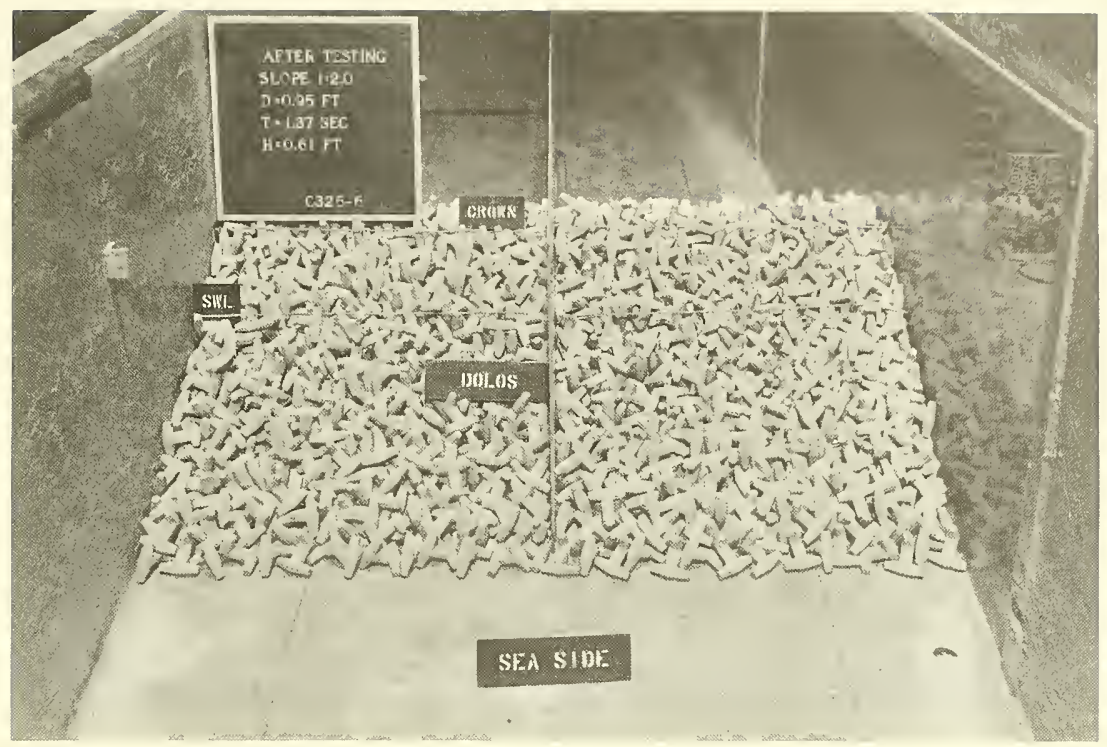

Photo 5. Sea-side view after attack of $1.37-\mathrm{sec}, 0.61-\mathrm{ft}$ waves; $\mathrm{d}=0.95 \mathrm{ft} ; \mathrm{W}_{\mathrm{a}}=0.276 \mathrm{lb} ; 1 \mathrm{~V}$-on-2H structure slope; dolos armor

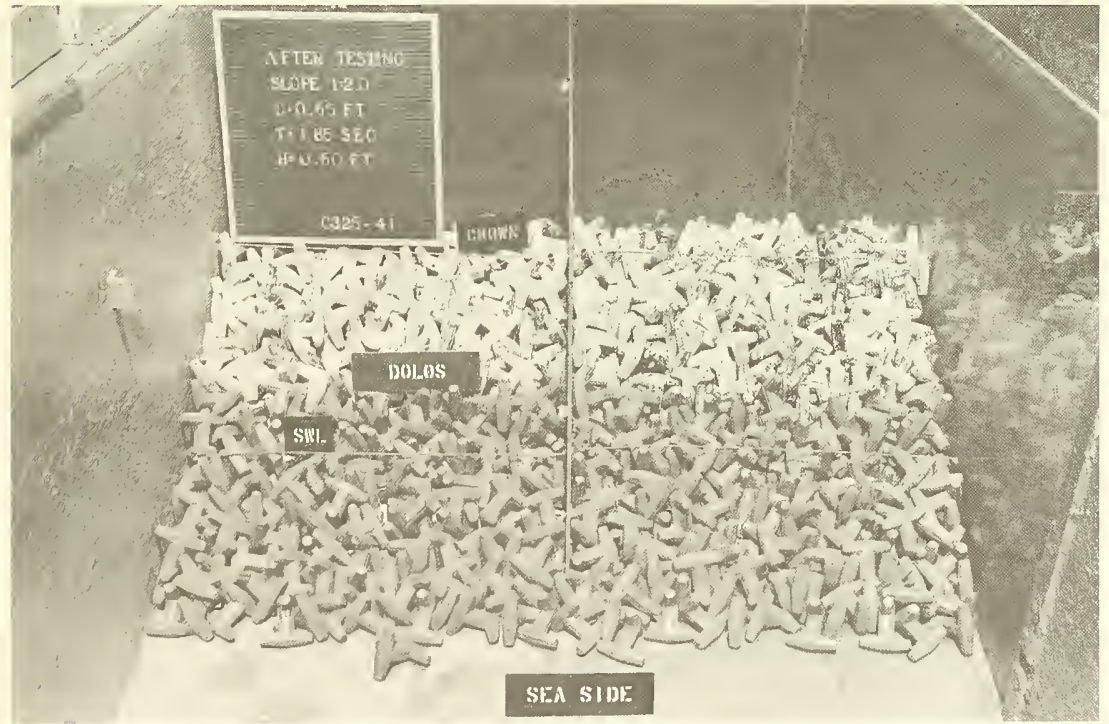

Photo 6. Sea-side view after attack of $1.85-\mathrm{sec}, 0.60$-ft waves; $\mathrm{d}=0.65 \mathrm{ft} ; \mathrm{W}_{\mathrm{a}}=0.589 \mathrm{1b} ; 1 \mathrm{~V}$-on-2H structure slope; dolos armor 


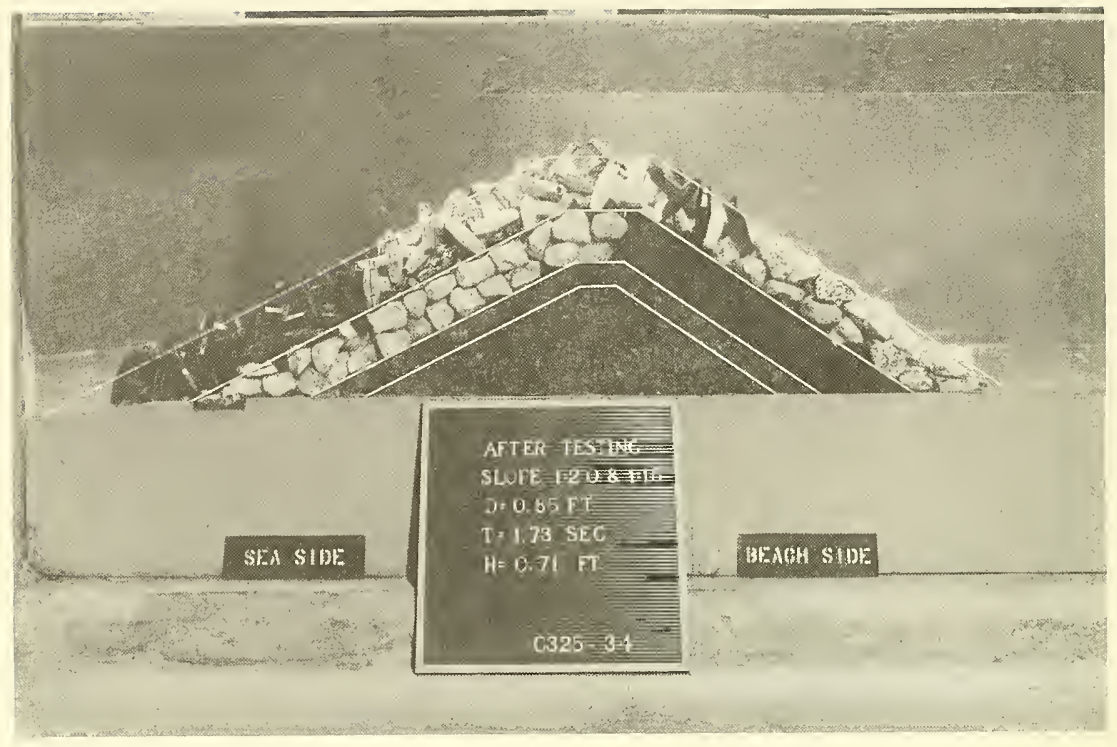

Photo 7. End view after attack of $1.73-\mathrm{sec}, 0.71-\mathrm{ft}$ waves; $\mathrm{d}=0.85 \mathrm{ft}$; $\mathrm{W}_{\mathrm{a}}=0.589 \mathrm{lb} ; 1 \mathrm{~V}$-on-2H structure slope; dolos armor

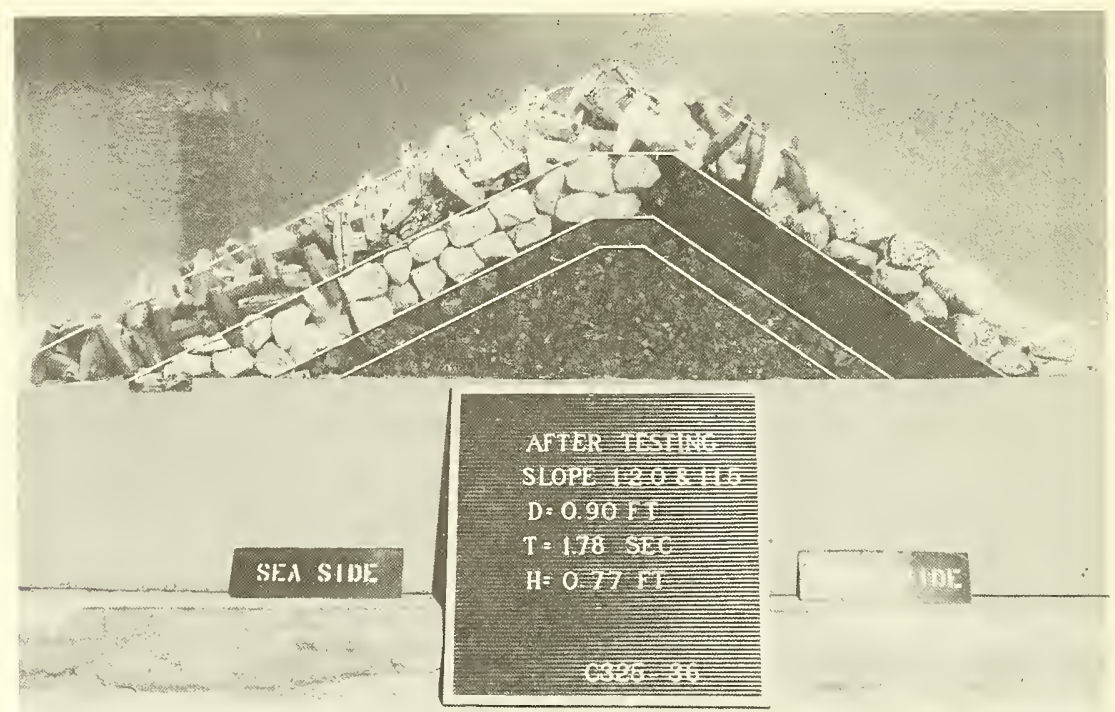

Photo 8. End view after attack of 1.78 -sec, $0.77-\mathrm{ft}$ waves; $\mathrm{d}=0.90 \mathrm{ft}$; $\mathrm{W}_{\mathrm{a}}=0.589 \mathrm{lb} ; \mathrm{IV}$-on-2H structure slope; dolos armor 


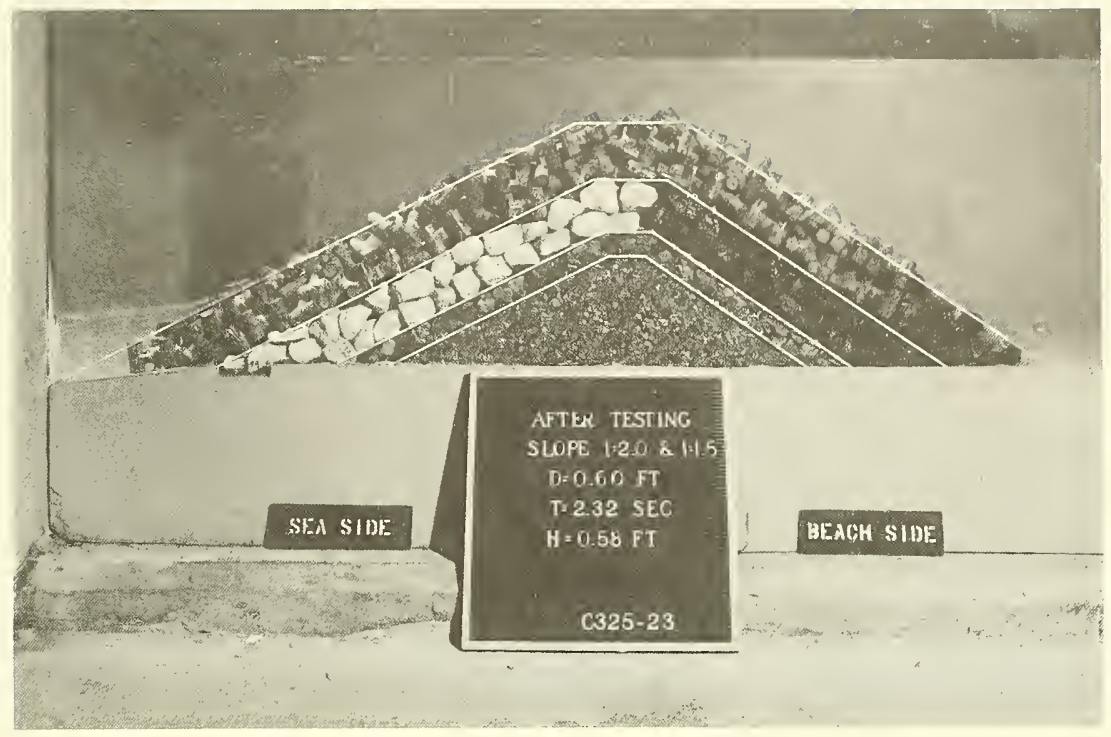

Photo 9. End view after attack of $2.32-\mathrm{sec}, 0.58-\mathrm{ft}$ waves; $d=0.60 \mathrm{ft}$; $\mathrm{W}_{\mathrm{a}}=0.6271 \mathrm{~b} ; 1 \mathrm{~V}$-on-2H structure slope; tribar armor

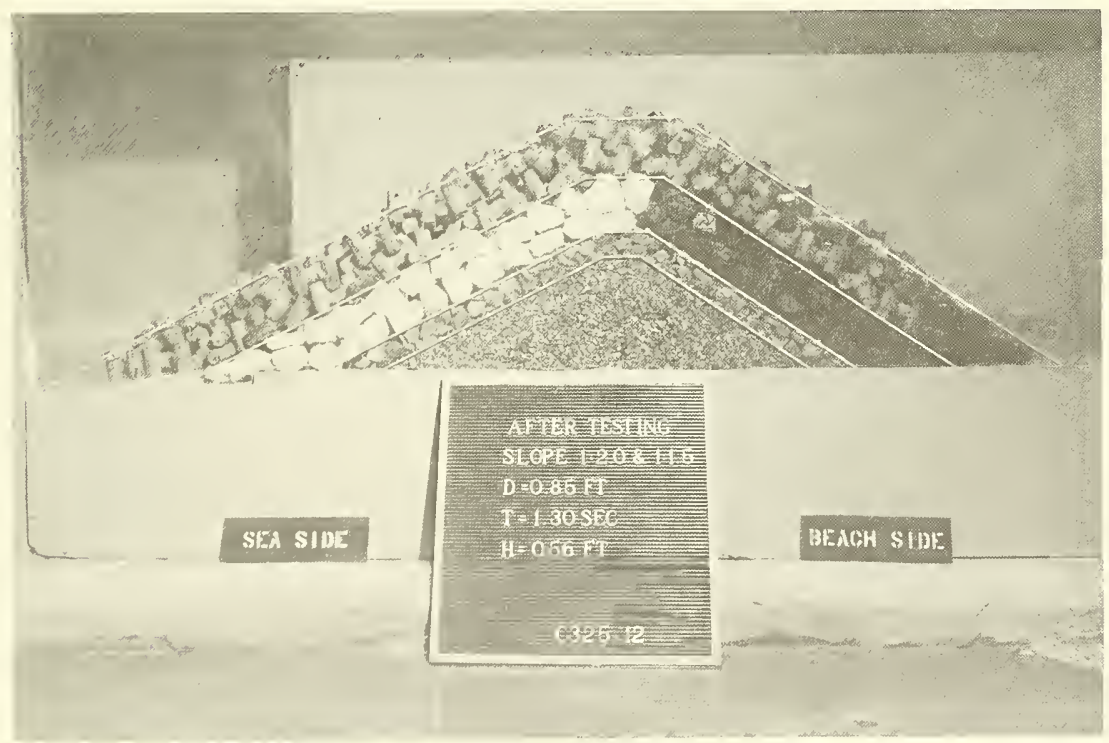

Photo 10. End view after attack of 1.30-sec, 0.56-ft waves; $\mathrm{d}=0.85 \mathrm{ft} ; \mathrm{W}_{\mathrm{a}}=0.627 \mathrm{1b} ; 1 \mathrm{~V}$-on-2H structure slope; 


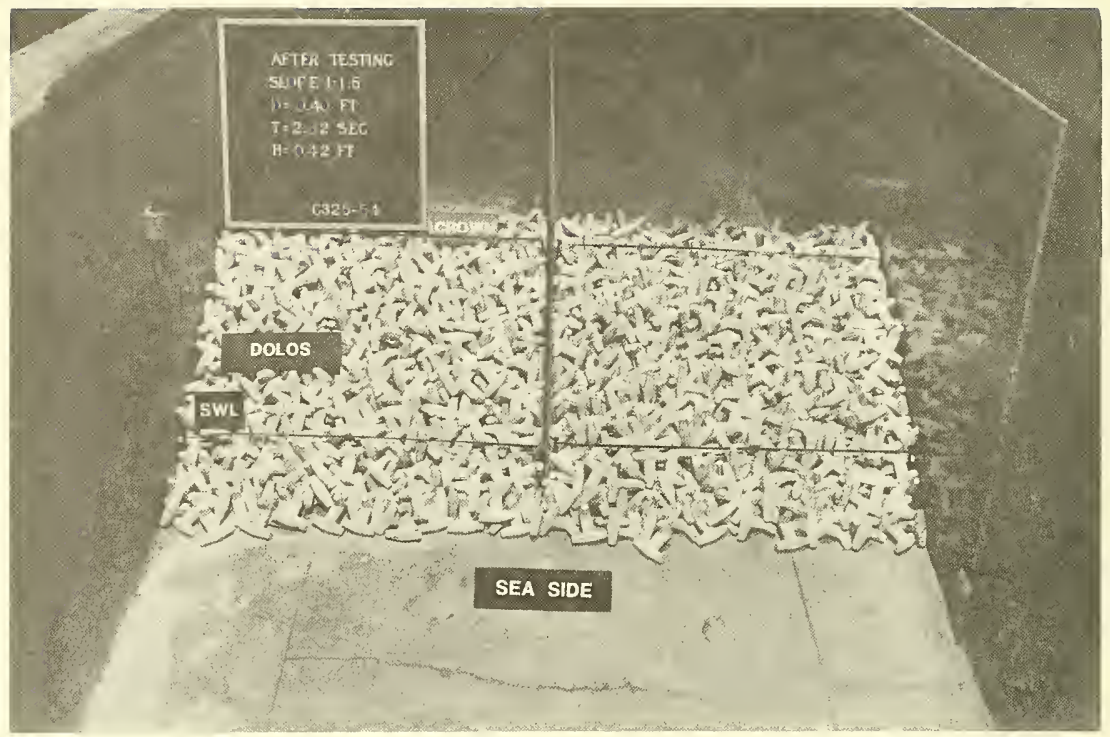

Photo 11. Sea-side view after attack of 2.82-sec, 0.42-ft waves; $\mathrm{d}=0.40 \mathrm{ft} ; \mathrm{W}_{\mathrm{a}}=0.276 \mathrm{lb} ; 1 \mathrm{~V}$-on-1.5H structure slope; dolos armor

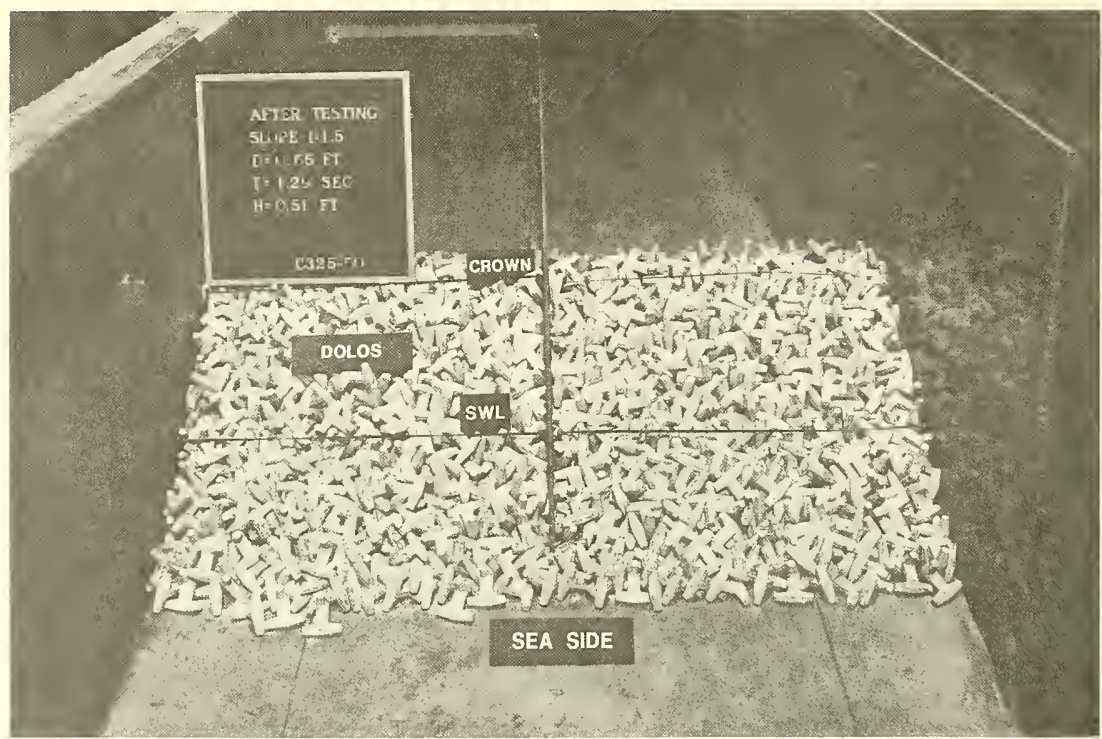

Photo 12. Sea-side view after attack of 1.29-sec, 0.51-ft waves; $\mathrm{d}=0.65 \mathrm{ft} ; \mathrm{W}_{\mathrm{a}}=0.276 \mathrm{lb} ; \mathrm{IV}$-on-1.5H structure slope; dolos armor 


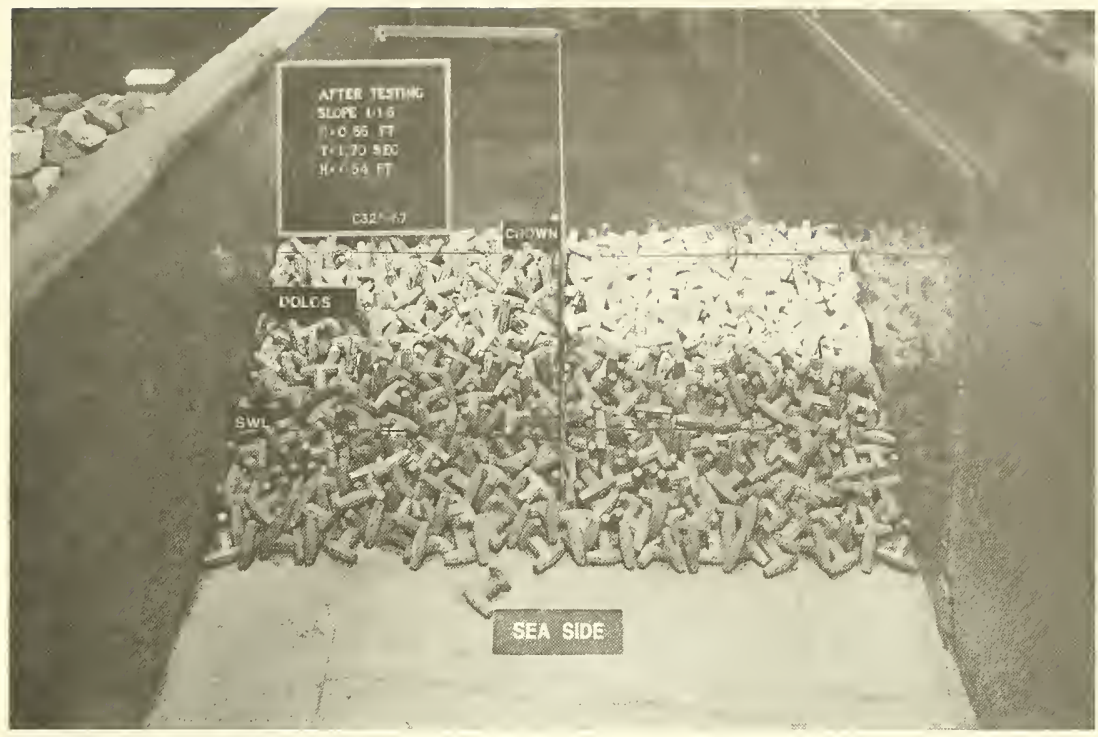

Photo 13. Sea-side view after attack of 1.70-sec, 0.54-ft waves; $\mathrm{d}=0.55 \mathrm{ft} ; \mathrm{W}_{\mathrm{a}}=0.589 \mathrm{1b} ; 1 \mathrm{~V}$-on-1.5H structure slope; dolos armor

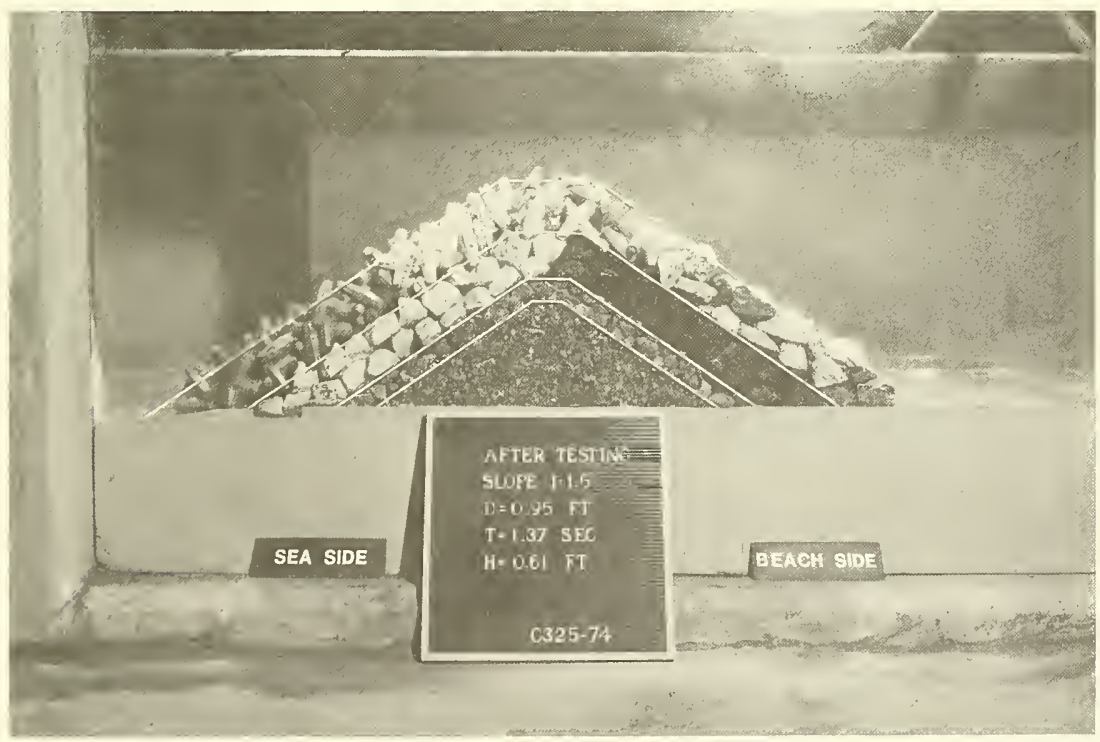

Photo 14. End view after attack of $1.37-\mathrm{sec}, 0.61-\mathrm{ft}$ waves; $\mathrm{d}=0.95 \mathrm{ft} ; \mathrm{W}_{\mathrm{a}}=0.589 \mathrm{1b} ; 1 \mathrm{~V}$-on-1.5H structure slope; dolos armor 


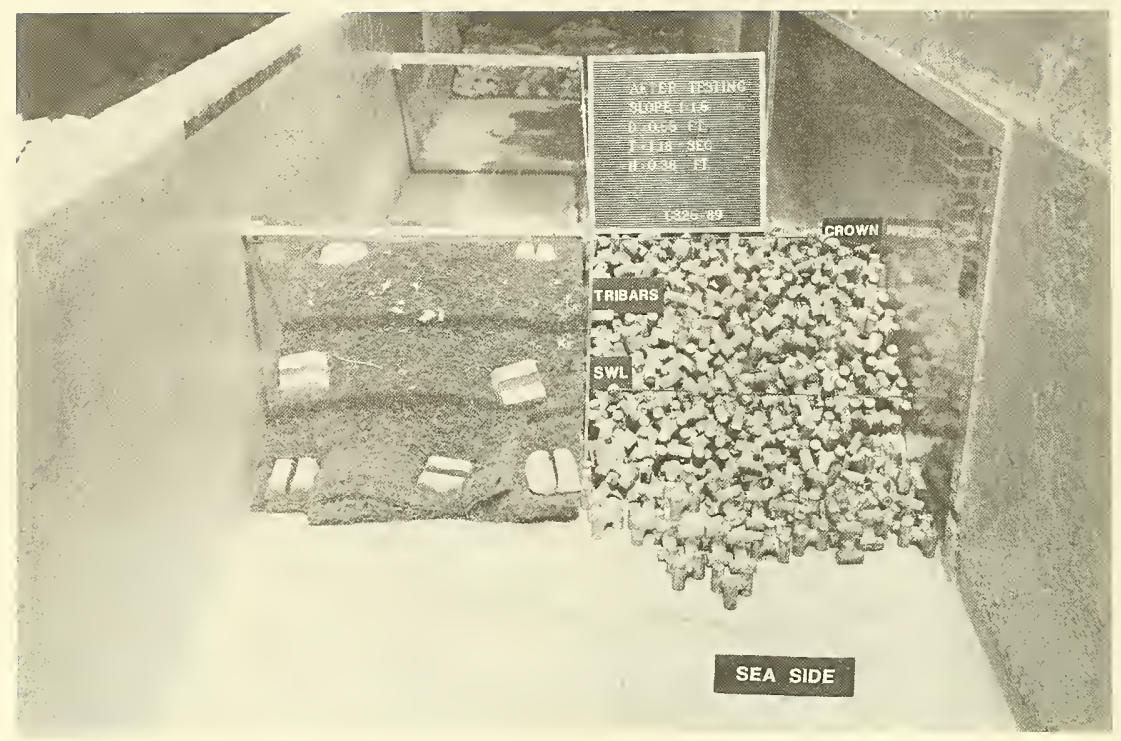

Photo 15. Sea-side view after attack of 1.18 -sec, 0.38 -ft waves; $\mathrm{d}=0.55 \mathrm{ft} ; \mathrm{W}_{\mathrm{a}}=0.627 \mathrm{lb} ; 1 \mathrm{~V}-\mathrm{on}-1.5 \mathrm{H}$ structure slope; tribar armor

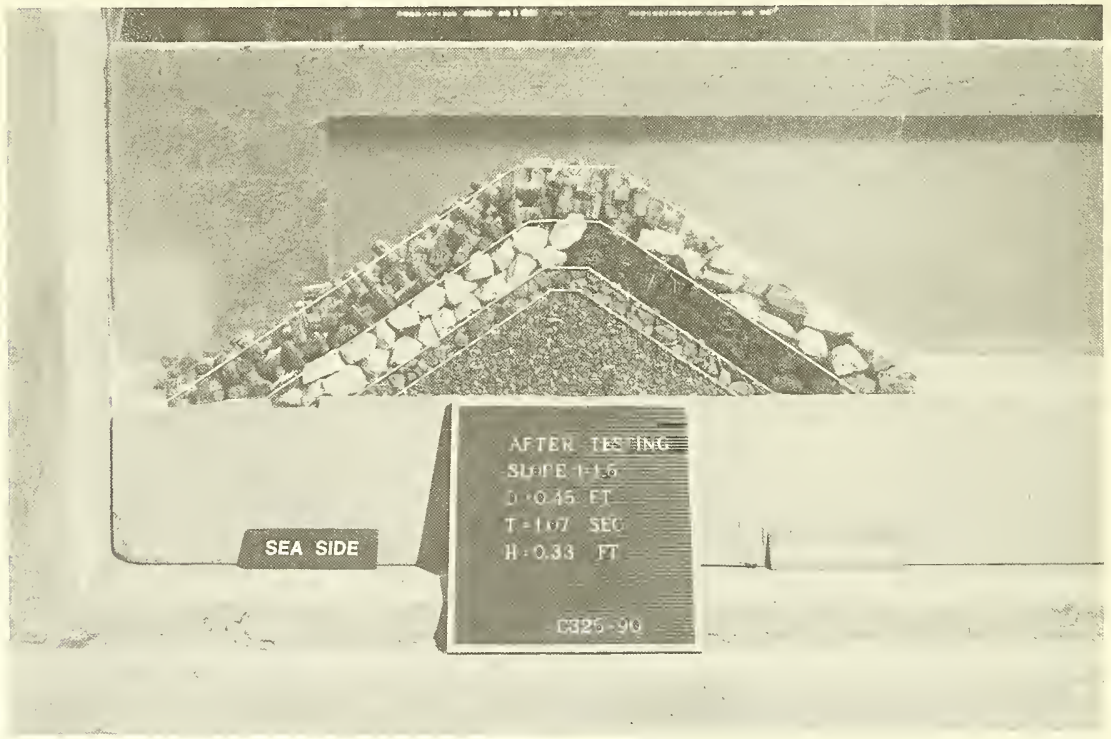

Photo 16. End view after attack of 1.07-sec, 0.33-ft waves; $\mathrm{d}=0.45 \mathrm{ft} ; \mathrm{W}_{\mathrm{a}}=0.627 \mathrm{lb} ; 1 \mathrm{~V}$-on-1.5H structure slope; tribar armor 


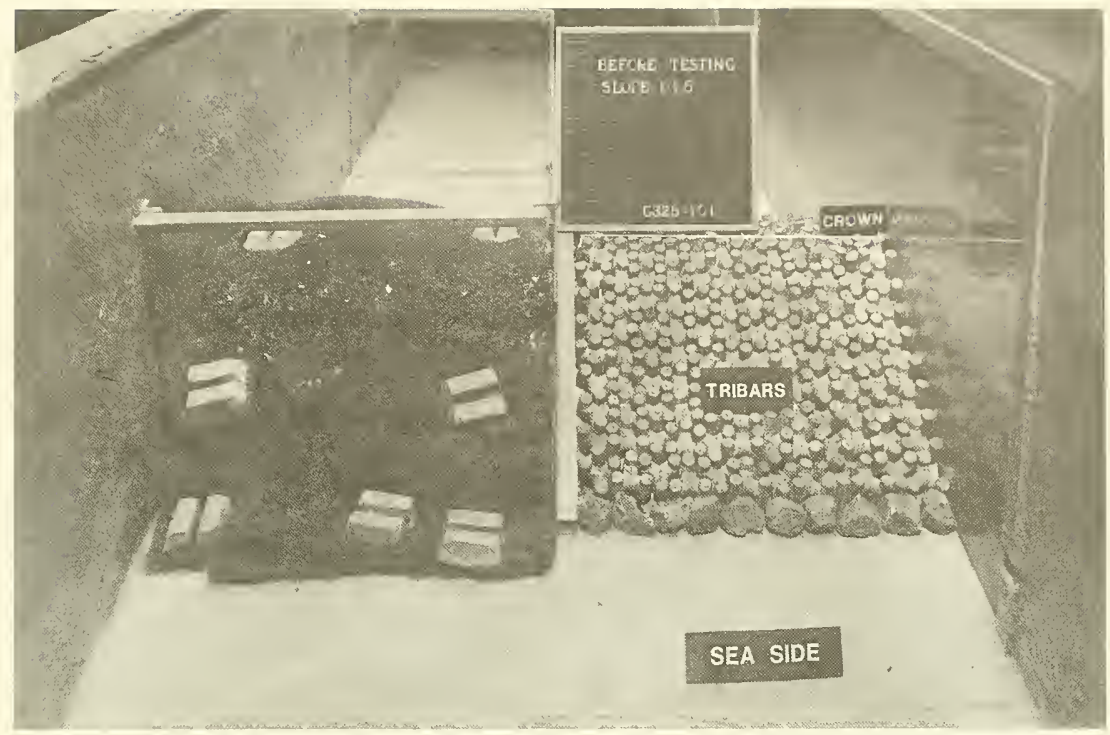

Photo 17. Sea-side view of uniformly placed tribar armor before wave attack at a $1 \mathrm{~V}$-on-1.5H structure slope

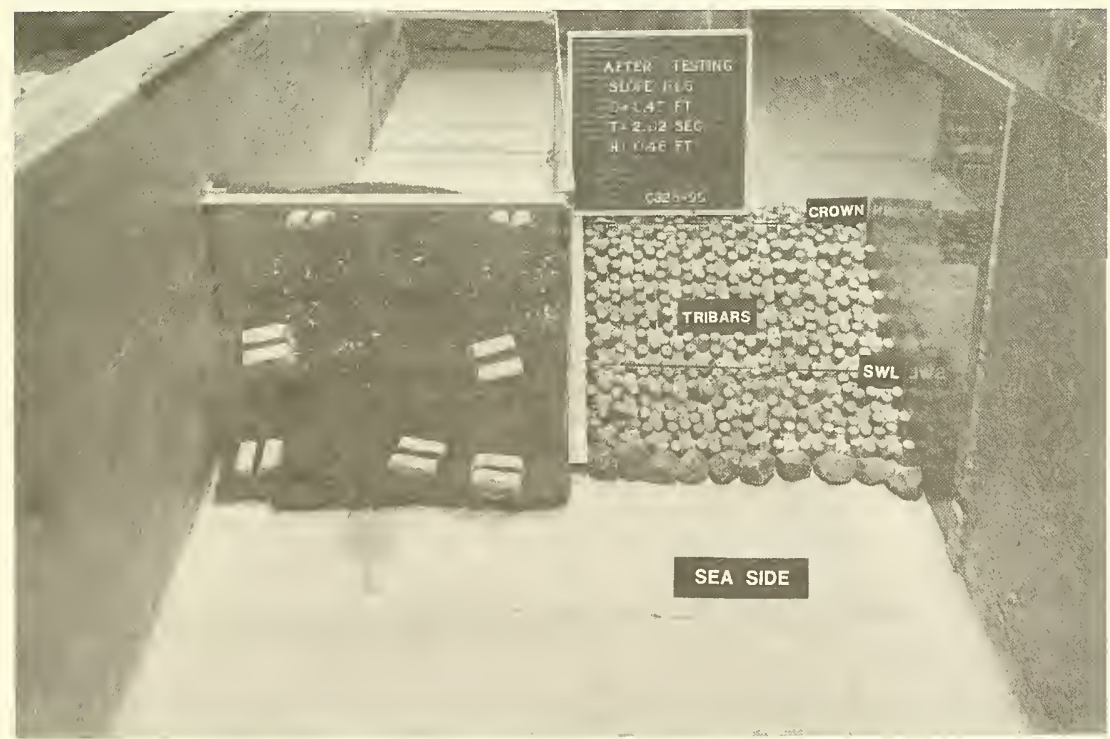

Photo 18. Sea-side view after attack of 2.02-sec, 0.46-ft waves; $\mathrm{d}=0.45 \mathrm{ft} ; \mathrm{W}_{\mathrm{a}}=0.6271 \mathrm{~b} ; 1 \mathrm{~V}$-on-1.5H structure slope; uniform $1 \mathrm{y}$ placed tribars 


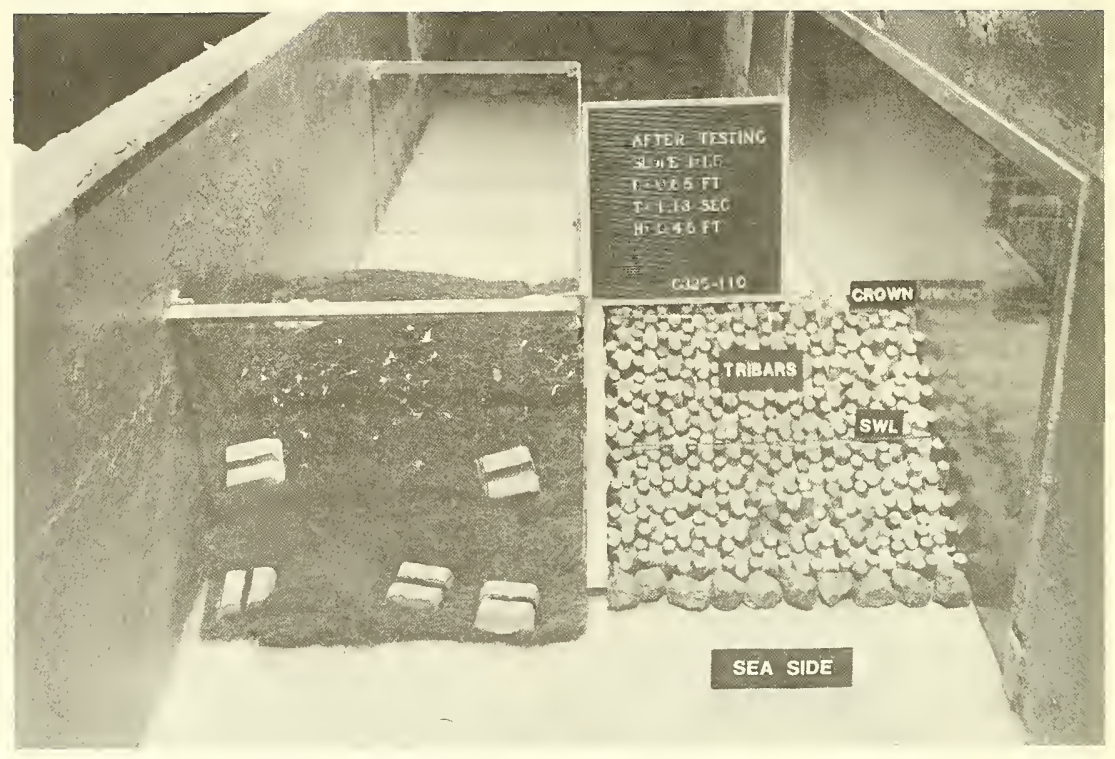

Photo 19. Sea-side view after attack of 1.13-sec, 0.46-ft waves; $\mathrm{d}=0.65 \mathrm{ft} ; \mathrm{W}_{\mathrm{a}}=0.627 \mathrm{lb} ; \mathrm{IV}$-on-1.5H structure slope; uniformly placed tribars 


\section{APPENDIX A: NOTATION}

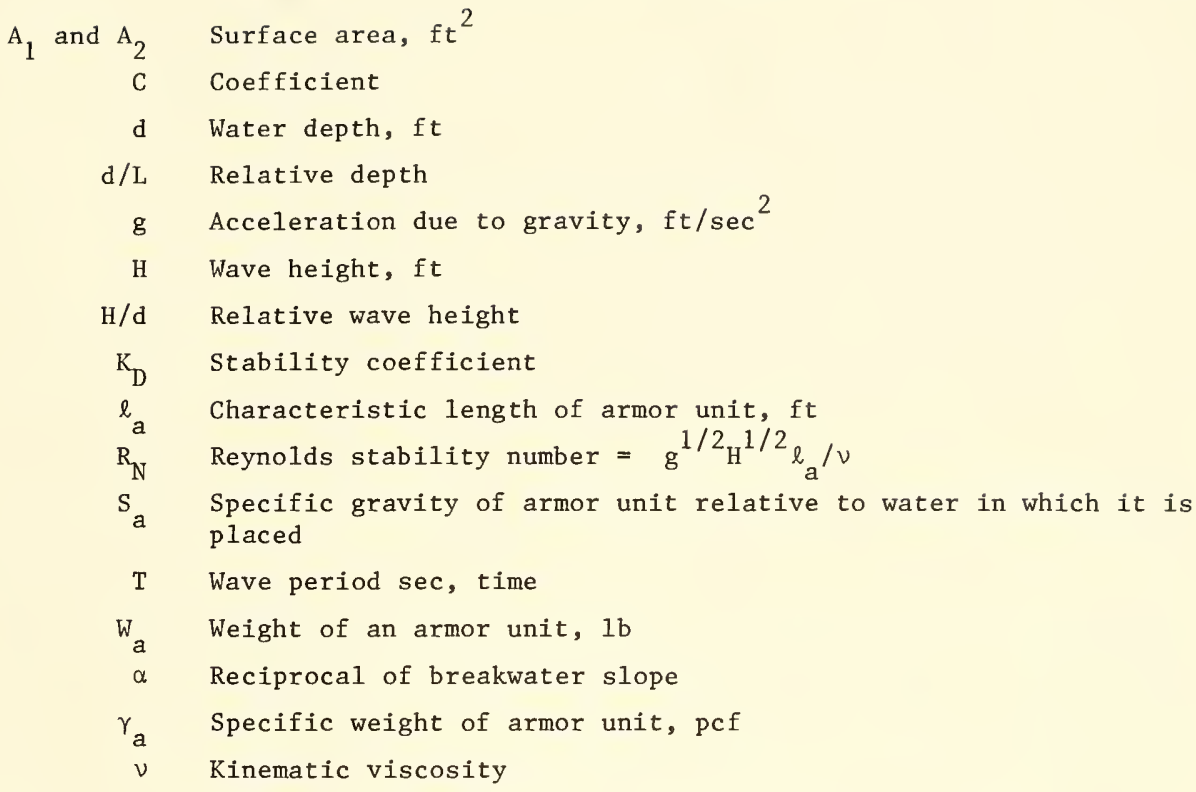



